Running title: Treg and Th17 cells: a special relationship

\title{
The special relationship in the development and function of $T$ helper 17 and regulatory $\mathrm{T}$ cells
}

Matthias Lochner ${ }^{1,2}$, Zuobai Wang $^{1,2}$ and Tim Sparwasser ${ }^{1}$

${ }^{1}$ Institute of Infection Immunology, TWINCORE, Centre for Experimental and Clinical Infection Research; a joint venture between the Medical School Hannover $(\mathrm{MHH})$ and the Helmholtz Centre for Infection Research (HZI), Hannover, Germany;

${ }^{2}$ Contributed equally

Key words: Regulatory T cells, T helper 17 cells, immune regulation, infection, inflammation 


\section{Abstract}

T helper 17 (Th17) cells play an essential role in the clearance of extracellular pathogenic bacteria and fungi. However, this subset is critically involved in the pathology of many autoimmune diseases, e.g. psoriasis, multiple sclerosis, allergy, rheumatoid arthritis and inflammatory bowel diseases in humans. Therefore, Th17 responses need to be tightly regulated in vivo to mediate effective host defenses against pathogens without causing excessive host tissue damage. Foxp $3^{+}$regulatory $\mathrm{T}$ (Treg) cells play an important role in maintaining peripheral tolerance to self-antigens and in counteracting the inflammatory activity of effector $T$ helper cell subsets. Although Th17 and Treg cells represent two CD4 ${ }^{+} \mathrm{T}$ cell subsets with principal opposing functions, these cell types are functionally connected. In this review, we will first give an overview on the biology of Th17 cells and describe their development and in vivo function, followed by an account on the special developmental relationship between Th17 and Treg cells. We will describe the identification of Treg/Th17 intermediates and consider their lineage stability and function in vivo. Finally, we will discuss how Treg cells may regulate the Th17 cell response in the context of infection and inflammation, and elude on findings demonstrating that Treg cells can also have a prominent function in promoting the differentiation of Th17 cells. 


\section{T helper 17 cells}

Th17 cells were recognized as an independent $\mathrm{T}$ helper cell lineage and the cellular source of IL-17 in the year $2005^{1-3}$ although the production of this cytokine by T cells had already been described earlier. ${ }^{4,5}$ Since then, a plethora of studies and publications have shed light into the development and function of this important $\mathrm{T}$ cell lineage. It has become clear that besides the 'signature' cytokine IL-17A, Th17 cells can express an array of factors that include IL-17F, IL-6, IL-10, IL-22, GM-CSF, TNF $\alpha$, CCL20, CCL22, IL1R $\alpha$ or the IL-23R. In addition to the $C D 4^{+} \mathrm{TCR}_{\alpha} \beta^{+}$Th17 cells, other IL-17-producing cells have been identified, such as subsets of TCR $\gamma \delta^{+}$T cells $^{6}$, invariant NKT cells ${ }^{7}$ or subpopulations of group 3 innate lymphoid cells (ILC). ${ }^{8}$

\section{The development of Th17 cells}

The path for the discovery of Th17 cells was opened in the year 2003 by the seminal finding that the autoimmune pathology observed in experimental autoimmune encephalomyelitis (EAE), the murine model of multiple sclerosis, was not dependent on IL-12 and thus Th1 cells, but rather on the cytokine IL-23. ${ }^{9}$ This was followed by the discovery that IL-23 promotes the development and expansion of an IL-17-producing CD4 ${ }^{+} \mathrm{T}$ helper cell lineage that was eventually termed Th17 cells. ${ }^{1-3}$ Nevertheless, IL-23 alone cannot drive the differentiation of naïve T cells into Th17 cells, and it was shown simultaneously by several groups, that the addition of TGF- $\beta 1$ and IL-6 during initial TCR activation promotes the differentiation of Th17 cells. ${ }^{10-12}$ IL-6 plays a crucial role during the initial phase by activating signal transducer and activator of transcription (STAT)3, which directly promotes the transcription of Th17 specific genes such as Rorc (encoding for retinoic acid receptor-related orphan receptor (ROR) $\gamma \mathrm{t}$ in T cells), $I / 17$ and $/ 123 r .{ }^{13}$ ROR $\gamma \mathrm{t}$ was first cloned as a shorter isoform of the hormone receptor ROR $\gamma$ and described to be expressed in the thymus and in $\mathrm{T}$ cell lines. ${ }^{14}$ Besides its function in the context of thymocyte development ${ }^{15-18}$, further studies demonstrated that ROR $\gamma$ t is expressed in lymphoid tissue inducer cells ${ }^{19}$, and thus plays an important role for lymphoid tissue development as well as for the function of group 3 innate lymphoid cells (ILC3). ${ }^{20,21}$ However, work by the Littman group demonstrated in 2006 that ROR $\gamma t$ was necessary for the development and function of the newly discovered CD4 ${ }^{+}$Th17 cell lineage, clearly defining ROR $\gamma \mathrm{t}$ as the 'master transcription factor' for Th17 cells. ${ }^{22}$ ROR $\gamma \mathrm{t}$ directly regulates the transcription of Th17 specific genes such as $I 117, \| 17 f$ and $I / 23 r$ and is a critical component of a larger network of transcription factors like STAT3, IRF4 or BATF. This transcriptional network collectively initiates the complete Th17 differentiation program and is important to maintain Th17 lineage stability. ${ }^{13,23}$ Besides IL-6, which is crucial for initiating Th17 lineage specification, IL-21 has been demonstrated to serve as an autocrine factor important for growth and expansion of Th17 cells. ${ }^{24,25}$ 
Another important proinflammatory cytokine for the induction of Th17 cells is IL-1 $\beta$. The expression of IL1R during the initiation phase of Th17 cells is induced by IL-6, and signaling through the IL1R leads to enhanced IRF4 expression, which in turn further promotes the expression of ROR $\gamma \mathrm{t}^{26}{ }^{26}$ Interestingly, it has been demonstrated that mechanistically, the role of IL-1 $\beta$ in enforcing Th17 differentiation is mediated via its capacity to activate the mTOR pathway. ${ }^{27}$ mTOR is an important regulator of the cellular metabolism, and its activation is crucial for the TCR-mediated development of naïve $T$ cells into effector $T$ cells. One important function of mTOR is the activation of catabolic pathways, and especially the induction of aerobic glycolysis and de novo fatty acid synthesis, which play an essential role in Th17 differentiation. ${ }^{28-30}$ In line with these findings, activation of the transcription factor HIF1 $\alpha$, a downstream target of mTOR and an important positive regulator of glycolysis, has been shown to critically contribute to Th17 lineage development. ${ }^{31,32}$ These latter results nicely illustrate how signaling pathways influence changes in basic cellular metabolic processes that are necessary to allow for the development of Th17 cells.

\section{Evidence for a high functional diversity and lineage plasticity of Th17 cells}

In contrast to IL- 6 and IL-1 $\beta$, the role of TGF- $\beta$ in Th17 differentiation is less well understood. There is ample evidence that TGF- $\beta$ is of significance for Th17 development in vivo ${ }^{33-35}$ and, as mentioned above, the combination of TGF- $\beta$ and IL-6 efficiently generates Th17 cells in vitro. Nevertheless, it is possible that a prominent function of TGF- $\beta$ during Th17 differentiation is to suppress skewing into Th1 or Th2 direction. ${ }^{36}$ In line with this notion, it was shown that Th17 cells could be efficiently generated in response to IL-1 $\beta$, IL- 6 and IL-23 in a TGF- $\beta$-independent manner. ${ }^{37}$ However, while Th17 cells that are generated in the presence of TGF- $\beta$ and IL- 6 are only weakly pathogenic and express significant levels of IL$10^{38}$, it has become clear that presence of IL-23 is critical for the differentiation of pathogenic Th17 cells. ${ }^{37,39,40}$ In fact, it is very likely that the in vivo environment and the presence of specific factors and cytokines govern a high degree of functional plasticity within the Th17 lineage. In that respect, it has been shown recently in a model of anti-CD3-induced intestinal inflammation that Th17 cells can be re-directed into a regulatory phenotype. This was shown to be dependent on the CCL20-CCR6 dependent recruitment of Th17 cells into the intestine and the induction of immune-suppressive factors such as IL-10 in these cells. ${ }^{41}$ Along the same line, it was demonstrated that in the absence of sufficient amounts of IL-23, the cytokines IL-12 and IL-27 can drive pre-committed Th17 cells into an IL-10-secreting, Tr1-like phenotype. $^{42}$ In contrast, presence of IL-23 induces autocrine production of TGF- 33 from developing Th17 cells, which in concert with IL-6 induced the development of very pathogenic Th17 cells, further demonstrating the importance of IL-23 for the development of proinflammatory Th17 cells. ${ }^{43}$ In addition, this study by the Kuchroo group demonstrated that 
TGF- $\beta 3$-induced pathogenic Th17 cells displayed a molecular distinct pattern compared to the classic TGF- $\beta 1$ induced Th17 cells, including the expression of several Th1-associated molecules such as T-bet. Indeed, several studies have shown that IL-23 induces the upregulation of the Th1 transcription factor T-bet with concomitant IFN- $\gamma$ expression in Th17 cells $^{37,44-46}$, and such IL- $17^{+} \mathrm{IFN}-\gamma^{+}$cells have been associated with an enhanced reactivity and pathological potential, e.g. in the intestine. ${ }^{47-50}$ This functional diversity of Th17 cells is accompanied by a considerable tendency for lineage plasticity. In other words, the expression of IL-17A/F and ROR $\gamma$ t (the minimal requirements for $C D 4^{+} \mathrm{T}$ cell to be considered as a Th17 cell) may not reflect the end stage of Th17 effector/memory development, but represent a more or less stable intermediate within the transition into other functional $T$ helper cell lineages. Consistent with this idea, IL-17 production in in vitro polarized Th17 cells is unstable and lost after several rounds of restimulation, leading eventually to an IFN $\gamma^{+}$Th1 phenotype. ${ }^{51-53}$ In addition, studies with purified in vitro-generated Th17 cells transferred to NOD mice revealed tissue infiltrating cells changing their phenotype to become Th1 cells. ${ }^{54,55}$ Using a fate mapping strategy in vivo, it was demonstrated that the majority of $T$ cells that expressed IL-17A/F at some stage their life cycle, had lost IL-17 expression at the time point of analysis. ${ }^{44,56}$ Fate mapping of IL-17A-expressing reporter $\mathrm{T}$ cells in the context of experimental autoimmune encephalomyelitis (EAE) revealed that Th17 cells downregulate their IL-17 and ROR $\gamma$ t expression and switch to a Th1-like phenotype. ${ }^{44}$ Importantly, the results of this study suggest that IFN- $\gamma$ and other proinflammatory cytokines in the spinal cord were produced almost exclusively by cells that had produced IL-17 before their conversion, indicating that Th17 cells indeed converted into more pathogenic 'exTh17' cells, at least under the chronic inflammatory conditions of this model. Nevertheless, recent evidence suggests that Th17 cells can also go along a different path and switch into IL-17negative Tr1-like cells with a regulatory function. Using a triple transgenic IL-17 fate mapping / IL-10 reporter approach, Gagliani and colleagues showed that Th17 cells transdifferentiate in the anti-CD3-induced model of intestinal inflammation as well as during $S$. aureus mediated sepsis into suppressive IL-10 'exTh17' cells with low expression of ROR $\mathrm{t}$, Foxp3 and genes associated with Th1 or Th2 cells. ${ }^{57}$ Interestingly, the authors found that this conversion was dependent on TGF-ß1 signaling through Smad3 and could be enhanced by activation of the aryl hydrocarbon receptor (AhR) expressed on TGF-ß1-induced Th17 cells. Another example of Th17 lineage conversion was described by the Stockinger group again using IL-17A fate mapping mice. ${ }^{58}$ Under non-inflammatory conditions, transferred Th17 cells preferentially homed to the intestine and were found to convert into functional follicular $\mathrm{T}(\mathrm{fh})$ helper cells in the Peyer's patches, as illustrated by loss of IL-17 and ROR $\gamma$ t expression and the concomitant upregulation of Tfh-specific factors such as CXCR5, IL-21 and Bcl6. 
Although these studies indicated that Th17 can readily lose their phenotype, it should be noted that converted Th17 cells may still carry specific traits that differentiates them from other Th cell lineages. The study by Muranski et al. suggests that IFN- $\gamma^{+} \mathrm{T}-$ bet $^{+}$'exTh17' cells differ significantly in their molecular expression profile compared to classical derived Th1 cells. ${ }^{59}$ In addition, it has been demonstrated that Th17 cells can be long lived and display a high potential for self-renewal in mice as well as in humans. ${ }^{59,60}$

\section{Induction of Th17 cells under physiological conditions in vivo}

Under normal physiological conditions the greatest number of ROR $\gamma \mathrm{t}^{+} \mathrm{Th} 17$ cells is found in barrier tissues like the skin, the mucosa of the respiratory tract and especially in the lamina propria of the intestine. ${ }^{22,61}$ Interestingly, the presence of microbiota is absolutely required for the induction of Th17 cells in the intestine, since germ-free mice do not contain IL-17/IL-22 producing Th17 cells. ${ }^{62-64}$ A particular potent bacterial inducer of Th17 cells is Candidatus arthromitus (also known as segmented filamentous bacteria, SFB) ${ }^{63}$, and it was demonstrated that Th17 cells within the small intestine possess a distinct TCR repertoire that recognizes and specifically responds to SFB-antigens. ${ }^{65,66}$ However, even though SFB is a very efficient inducer of Th17 cells, it also induces other types of Thelper cells such as Th1, Th2 and Treg as well as the production of $\operatorname{lgA} .{ }^{62,67}$ Furthermore, other groups of bacteria can also efficiently induce Th17 cells in the intestine. ${ }^{62,64}$ Despite the strict requirement for the presence of microbes, intestinal Th17-induction was initially shown to be independent of MyD88/TRIF- and NOD-transmitted signals, and thus independent of classic microbeassociated molecular pattern (MAMP) ${ }^{63,68,69}$ Instead, colonization with SFB results in strong upregulation of Serum Amyloid A (SAA), a member of the family of acute-phase response proteins induced during infection, tissue damage, or inflammatory disease. SAA can induce Th17 differentiation, at least in vitro, by stimulating IL-6 and IL-23 expression by dendritic cells (DC). ${ }^{63}$ This finding is in line with several reports demonstrating the important role of DC for the induction of intestinal Th17 cells. In the intestine, loss or reduction of a specific population of DC characterized by the expression of CD103 and CD11b, as observed in mice with a DC-specific deletion in IRF4, Notch2 or in human Langerin-DTA mice, results in significantly reduced numbers of Th17 cells. ${ }^{70-74} \mathrm{CD} 103^{+} \mathrm{CD} 11 \mathrm{~b}^{+} \mathrm{DC}$ can express high levels of IL-6 and/or IL-23 $3^{71-73}$, suggesting that $C D 103^{+} C D 11 b^{+} D C$ contribute to the development of intestinal Th17 mainly by the production of those cytokines. Interestingly, the addition of ligands for several TLRs, including TLR2, TLR5 and TLR9 to in vitro cultures strongly induce

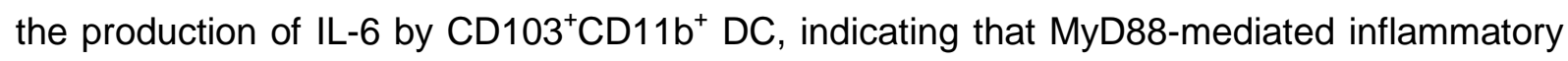
signals are required for their ability to induce Th17 cells. ${ }^{71,75,76}$ Previous data highlighted the specific expression of IL-23 by a subset of intestinal TLR5 ${ }^{+} \mathrm{CD} 11 \mathrm{~b}^{+} \mathrm{DC}$ in promoting Th17 T helper cells. ${ }^{77}$ In addition, a recent study further emphasized the crucial role of 


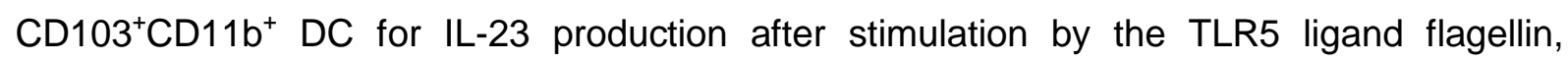
although the direct impact on Th17 induction was not analyzed in this study. ${ }^{78} \mathrm{~A}$ direct role for IL-1 $\beta$ in the microbiota-mediated in induction of intestinal Th17 cells was also shown. $\mathrm{CD} 11 \mathrm{~b}^{+} \mathrm{CD} 11 \mathrm{c}^{-/ \mathrm{llow}}$ macrophages were identified as the main source of IL-1 $\beta$ and, importantly, the induction of IL-1 production was shown to be dependent on MyD88-signalling. ${ }^{79}$ Thus, while there is now good evidence for an essential role of DC, the exact contribution of MyD88-mediated signals for Th17 development is less clear. It is possible that redundant layers of Th17-inducing factors exist in vivo that depend on the actual presence of specific environmental factors or the status and composition of the intestinal flora. In this regards, it has been shown that microbiota-derived ATP can increase Th17 cell numbers in the colon, probably by binding to purinergic receptors on gut residing $\mathrm{CD} 70^{+} \mathrm{DC} /$ macrophage subpopulations, leading to the induction of MyD88-independent IL-6, TGF- $\beta$ and IL-23 production. ${ }^{68}$ In addition, signals through Ahr, which recognizes ligands such as xenobiotic or natural arising toxins as well as ligands typically found in fruits and vegetables, may influence either directly or indirectly the development and function of Th17 cells. Initial studies have shown that Ahr is expressed on Th17 cells and that ligation with specific agonizing ligands can enhance Th17 development. ${ }^{80,81}$ Furthermore, T cells derived from Ahr-deficient animals displayed reduced IL-17 and IL-22 expression and less potential to induce Th17-mediated disease. ${ }^{81-83}$ Nevertheless, the exact role of Ahr in Th17 cell development and function in vivo is not completely understood. Recent studies indicate that Ahr deficiency mainly affects the function and maintenance of innate cells such as $\mathrm{TCR} \gamma \delta^{+}$intra epithelial cells and group 3 ILCs. ${ }^{84,85}$

\section{Role of Th17 cells in infection and inflammation}

IL-17A, IL-17F and IL-22, produced by Th17 cells, bind to the receptors for IL-17A/F and IL22 on the basal surface of intestinal epithelial cells, to produce antimicrobial peptides/proteins, e.g. lipocalin-2, $\beta$-defensins, Calprotectin, RegllI $\beta$, Reglll $\gamma$ or S100A. These antimicrobial molecules in turn limit bacterial penetration through the single cellepithelial barrier and further mediate the clearance of invading microorganisms. ${ }^{86-88}$ In addition, IL-22 also induces epithelial proliferation via STAT3 signaling, which facilitate wound healing and recovery from pathological damaged caused by inflammation. ${ }^{89}$ In response to self-produced IL-21, Th17 cells in turn expand during pathogen infection, which will boost the pathogen-specific Th17 cell response. Moreover, IL-21 together with IL-17 supports the formation of lymphoid tissues in the gut and facilitates the production of antipathogen antibodies to kill pathogens..$^{90}$ In addition to these mechanisms mediated by Th17 cells, this cell type is regarded as a master regulator of neutrophil-meditated clearance of invading microbes. Th17-derived cytokines induce granulopoietic factors like G-CSF or GM- 
CSF and several CXC chemokines indirectly facilitate neutrophil development, proliferation, recruitment and function. ${ }^{90}$ In addition, a recent study illustrates that human Th17 cells also directly secrete CXCL8 (also known as IL-8), IFN-y, TNF and GM-CSF to recruit, activate and sustain the survival of neutrophils at the site of infection or inflammation. ${ }^{91}$ As a result of their production of the inflammatory cytokines and molecules, Th17 cells mediate effective protective immune defenses against invading pathogens, especially to extracellular bacteria and fungi at mucosal sites. ${ }^{86}$

Initial reports have indicated that Th17 cells play a pivotal role in the host response against pulmonary infections. IL-17RA knockout (KO) mice showed a delay in neutrophil recruitment and displayed greater dissemination of Klebsiella pneumonia. This effect was mediated mainly through decreased production of IL-17 downstream molecules such as GCSF and CXCL2. ${ }^{92}$ The importance of Th17 cells in host defense against pulmonary infections is further emphasized in patients suffering from the autosomal dominant hyper IgE syndrome (HIES), also known as Job's syndrome. This disease is characterized by recurrent staphylococcal pneumonia, mucocutaneous candidiasis, elevated serum $\lg \mathrm{E}$ and abnormalities of bone and connective tissues. Interestingly, it has recently been demonstrated that the underlying cause for this disease is a dominant negative mutation in STAT3. ${ }^{93,}{ }^{94}$ The involvement of STAT3 and the consequent deficiency in Th17 induction seems to play an important role in the increased susceptibility towards the pulmonary infection, especially in mucocutaneous candidiasis. ${ }^{95,96}$ Data derived from mouse models of candidiasis underline the significance of Th17 responses for the protection of the host. Mice deficient for molecules involved in the Th17 response such as IL17RA, IL-17RC, IL-23 or Act display enhanced susceptibility towards oropharyngeal candidiasis. ${ }^{95,} 97,98$ Similar, IL-23- as well as IL-17A-deficient mice were shown to be susceptible towards dermal candidiasis. ${ }^{99}$ Candida albicans can also cause disseminated infections leading to high mortality rates, and mice deficient for IL-17RA or IL-17A show enhanced susceptibility to this type of infection. ${ }^{100-}$ ${ }^{102}$ Although there is evidence that IL-17 produced by innate cells such as ILC or TCR $\gamma \delta^{+} \mathrm{T}$ cells may be essential for the host defense against $C$. albicans ${ }^{103}$, a recent report indicated that Th17 cells can confer long-term adaptive immunity to oral mucosal $C$. albicans infections. $^{104}$

Th17 cells are likely to be involved also in the protection of the host from intestinal infections. It has been shown that infection with the murine gut-specific extracellular pathogen $C$. rodentium induces a robust Th17 cell response in the colon of the hosts. ${ }^{11,105}$ Mice deficient for IL-17A and/or IL-17F showed impaired clearance of C. rodentium and greater morbidity after $C$. rodentium infection at late time point of infection ${ }^{106}$, illustrating the essential role of IL-17 producing cells in this model. In line with this study, the SFB-induced Th17 cell response protects the host from C. rodentium-mediated morbidity and mortality, 
further confirming the importance of Th17 cell response against $C$. rodentium. ${ }^{63}$ Initial studies have shown the pivotal role of IL-23 for protection against $C$. rodentium infection. ${ }^{11}$ Although this cytokine plays a critical role for the pathogenicity and maintenance of Th17 cells as mentioned above, it is more likely that its major function during infection with $C$. rodentium is the activation of the ILC/IL-22 axis. In fact, ROR $\gamma \mathrm{t}^{+}$group 3 ILCs are major producers of IL-22 107-109, and mice that lack ILC3 or IL-22 are highly susceptible to intestinal infection with C. rodentium. ${ }^{109-111} \mathrm{IL}-22$ production by ILC3 can be induced by IL-23, which is secreted by intestinal DC after C. rodentium infection or intestinal TLR5 ligation. ${ }^{72,78,110,112}$ Nevertheless, the actual contribution of ILC3 and Th17 cells for host protection may depend on the colonization status of the mice. In that respect, Th17 cells that are imprinted by signals derived from the steady-state microbiota (designated as 'innate' Th17 cells) have been assigned a crucial role for the protection against $C$. rodentium as well as $S$. typhimurium at the very early phase of infection in the caecum of mice. ${ }^{113}$ Together, these studies suggest that Th17 cells are crucial to mediate effective host protection from the pathogenic infections, indicating that the concomitant low grade Th17-mediated tissue inflammation can be beneficial for the host. However, there are circumstances in which Th17 mediated immunity, including the recruitment of neutrophils to sites of infection, does not result in improved pathogen clearance, but instead leads to dysregulated inflammation without benefit to the host. Such examples, in which the Th17 response results in exacerbation of disease with enhances inflammation and pathology have been described for several infections including Aspergillus fumigatus-induced pneumonia as well as intestinal infection with C. albicans ${ }^{114}$, gut infection with Helicobacter pylori ${ }^{115,116}$ and after viral infections including respiratory syncytial virus (RSV), influenza virus ${ }^{117}$, Herpes virus and human rhinovorus. ${ }^{118}$

The critical contribution of Th17 cells to inflammation and autoimmunity in several disorders such as multiple sclerosis, psoriasis, rheumatoid arthritis, asthma or type 1 diabetes has been well documented. ${ }^{119}$ The cytokines and chemokines that are expressed by Th17 cells are found to be elevated in many of the described autoimmune diseases. Preclinical models have demonstrated that neutralization (or loss) of cytokines within the IL17-IL-23 axis can have impressive beneficial effects on the inflammatory response and the disease-associated pathology. ${ }^{120}$ Moreover, targeting of different Th17 factors by antibodies (e.g. against IL17A, IL-17RA, IL17A/F, IL17A/TNF or IL-23) has given encouraging results in human clinical trials. ${ }^{121}$ It should be noted however that clinical trials for the treatment of Crohn's disease, a form of inflammatory bowel disease, with IL-17-specific antibodies were terminated owing to a lack of efficacy or even disease exacerbation. ${ }^{122,}{ }^{123}$ These findings suggest that it is not IL-17 production, but rather the IL-23-mediated induction of a pathogenic Th17 phenotype that drives inflammation. In line with this, a large study found that a single nucleotide polymorphism in the IL23R was significantly associated with chronic 
inflammatory bowel disease in humans. ${ }^{124}$ Indeed there is evidence that in the intestine, some levels of IL-17 (or Th17 cells) are beneficial and protect from inflammation. Transfer of IL17A-deficient $T$ cells in the transfer colitis model of intestinal inflammation induced a stronger inflammatory response, associated with increased levels of IFN- $\gamma$ producing T cells. ${ }^{125}$ Likewise, antibody-mediated neutralization of IL-17 in the DSS colitis model aggravated disease, suggesting a protective role for IL-17 in intestinal inflammation. ${ }^{126}$ In line with these studies, a protective role for IL-17 has been proposed in Graft versus host disease (GvHD). Although different studies have shown partially contradicting results regarding the role of II-17 cytokines in GvHD, there is growing evidence that deficiency in IL-17 leads to aggravated GVHD in lung and colon, presumably due to upregulated Th1-responses. ${ }^{127}$ Thus, there is now clear evidence that Th17 cells, especially in concert with the IL-23 axis, have a pathogenic function in chronic inflammation and autoimmunity. Nevertheless, Th17derived cytokines, including IL-17 itself as well as IL-22, can contribute to tissue protection especially in the intestine, which emphasizes the importance of this cells type for normal intestinal homeostasis.

\section{Th17 cells and Treg cells: a special relationship}

T cells with suppressive functions were initially characterized as CD25 ( $\alpha$ subunit of IL-2 receptor) expressing $\mathrm{CD}^{+}{ }^{+} \mathrm{T}$ cells. ${ }^{128}$ It was shown that transfer of such 'suppressor' $\mathrm{CD} 4^{+} \mathrm{CD} 25^{+} \mathrm{T}$ cells confer protection from effector $\mathrm{T}$ cell induced autoimmune disease. Scurfy mice and patients with immunodysregulation, polyendocrinopathy, enteropathy $X$ linked (IPEX) syndrome share similar symptoms of massive aggressive autoimmunity and early death ${ }^{129-131}$, and it was found that mutations in the Foxp3 locus on the $\mathrm{X}$ chromosome are associated with the severe autoimmunity both in human and mice. ${ }^{131-133}$ Further studies illustrated that Foxp3 is exclusively expressed in $\mathrm{CD} 4^{+} \mathrm{CD} 25^{+}$Treg and is critical for the suppressive function of Treg. ${ }^{134,135}$ By using Foxp3 ${ }^{\text {GFP }}$ knock-in reporter mice, Fontenot and colleagues confirmed that Foxp3 is the critical lineage marker for CD4 ${ }^{+} \mathrm{TCR} \alpha \beta^{+}$Treg. ${ }^{134}$ Since their discovery, Foxp3 ${ }^{+}$Treg cells have been shown by many studies to be essential for suppression of effector $T$ cells and maintaining tolerance against self and foreign antigens. Genetic approaches that allow for specific depletion of Foxp3-expressing cells in mice ${ }^{136-138}$ have been instrumental to unravel the function of Foxp3 ${ }^{+}$Treg in inflammation, infection and cancer. ${ }^{136-141}$ According to the distinct origins and developmental programs, Treg are further divided into two subgroups - thymus-derived Treg (tTreg) and peripherally derived Treg (pTreg). Recent findings indicate that under homeostatic conditions, pTreg are of functional importance mainly at feto-maternal interfaces and for maintaining tolerance to food- and microbiota-derived antigens at mucosal sites. ${ }^{142-145}$ 
Th17 and Treg cells develop via a common Foxp $3^{+} R O R t^{+}$phenotype

An interesting aspect of Th17 development is the fact that it is functionally linked to the development of Foxp $^{+}$Treg cells. Despite their different functions in tolerance and inflammation, Treg and Th17 cells share the requirement for TGF- $\beta$ to develop from naïve $T$ cells. When activated in the presence of TGF- $\beta$ or $-T G F-\beta+I L-6$, naïve $T$ cells start to simultaneously upregulate both Foxp3 and ROR $\gamma \mathrm{t}$, and it has been shown that these transcription factors can directly interact with each other. ${ }^{61,146,147}$ From this intermediate Foxp $^{+} \mathrm{ROR} \gamma \mathrm{t}^{+}$stage, the cells can either differentiate into Foxp3 ${ }^{+}$Treg, or ROR $\gamma \mathrm{t}^{+} \mathrm{Th} 17$ cells. Importantly, Foxp3, in complex with ROR $\gamma$ t, can inhibit the transcriptional activity of RORyt. ${ }^{147,} 148$ Thus, under prevailing Treg-inducing conditions (e.g. high TGF- $\beta$ concentrations) the cells cannot differentiate into Th17 cells and develop eventually into Foxp $3^{+}$Treg cells. ${ }^{147}$ However, when inflammatory signals dominate (low TGF- $\beta$, presence of IL-6, IL-21 or IL1- $\beta$ ), Foxp3 activity is dampened and the cells develop into Th17 cells. ${ }^{146,147}$ Several mechanisms have been described that might account for the loss of Foxp3 under these conditions. HIF $1 \alpha$, which is induced and stabilized by inflammatory cytokines during Th17 development, can form a complex with Foxp3 and target it for proteasomal degradation. ${ }^{31}$ In addition, inflammatory signals like IL-1 $\beta$ or TNF- $\alpha$ can induce enhanced recruitment of E3 ubiquitin-protein ligase STUB1, which mediates Foxp3 ubiquitylation and marks it for subsequent degradation. ${ }^{149}$ In conclusion, Treg and Th17 cells develop from naïve $\mathrm{T}$ cells via a common Foxp ${ }^{+} \mathrm{ROR} \gamma \mathrm{t}^{+}$intermediate, and it is the specific environmental context of pro- or anti-inflammatory signals that induce the fundamental different outcomes from the same cellular target. This close developmental relationship between Treg cells and Th17 cells has gained considerable attention, since it may allow for a direct in vivo modulation of the Th17/Treg balance in inflammatory disorders. ${ }^{150}$

Function and stability of Foxp ${ }^{+} T$ cells that express the Th17 molecules ROR $\mathrm{rt}$ and IL-17

Reminiscent of the special relationship between Th17 and Treg cells described above, a high proportion of steady-state intestinal $\mathrm{ROR} \mathrm{t}^{+} \mathrm{T}$ cells have been found to simultaneously express Foxp3. ${ }^{61}$ Such Foxp ${ }^{+} \mathrm{ROR} \gamma \mathrm{t}^{+} \mathrm{T}$ cells have the ability to express IL-10 as well as IL17 and their expansion in the intestine depends at least in part on the presence of a complex microflora. ${ }^{61,64}$ Nevertheless, it is so far not clear whether these Foxp3 ${ }^{+} \mathrm{ROR} \gamma \mathrm{t}^{+} \mathrm{T}$ cells represent a stable phenotype with suppressive in vivo function. Moreover, their ability to induce IL-17 secretion indicates that they can participate in inflammatory reactions and may even convert into pathogenic ROR $\mathrm{t}^{+}$Th17 cells.

Using murine cells, it has been demonstrated that purified Foxp3 ${ }^{+}$Treg cells can be converted into IL-17 producing cells by DC activated with the dectin-1 ligand curdlan. ${ }^{151}$ IL17-production from Foxp3 ${ }^{+}$Treg can also be induced by co-culture of sorted Treg with APCs 
in the presence of IL-2 and IL $1 \beta{ }^{152,153}$ As expected, IL-17 expression in Foxp3 ${ }^{+}$cells is accompanied by expression of ROR $\gamma \mathrm{t}$ in those cells. In vivo, Foxp $3^{+} \mathrm{ROR} \gamma \mathrm{t}^{+}$cells have also been identified in mice under inflammatory conditions, such as type I autoimmune diabetes (TID) or relapsing-remitting experimental autoimmune encephalomyelitis (RR-EAE). ${ }^{154,} 155$ When analyzed for their function, $\operatorname{Foxp}^{+}\left(\mathrm{ROR} \gamma \mathrm{t}^{+}\right) \mathrm{IL}-17^{+}$cells showed a clear suppressive function and a stable expression of Foxp3, at least in the in vitro converted Treg cells. ${ }^{151-153,}$ 155 The in vivo situation may still be more complicated and it has been argued that the Foxp $3^{+} \mathrm{ROR} \gamma \mathrm{t}^{+}$cells observed in TID represent intermediates that can differentiate either towards Foxp3 ${ }^{+}$ROR $\gamma \mathrm{t}^{-}$Treg or ROR $\mathrm{t}^{+} \mathrm{Foxp}^{-}$Th17 cells. ${ }^{155}$ Nevertheless, the analysis of the phenotype of Foxp3 $3^{+} \mathrm{IL}-17^{+}$cells in the RR-EAE model revealed that most of the Foxp3 ${ }^{+}$ cells expressing IL-17 display an CD25 phenotype and might hence not represent a stable suppressive Treg population. ${ }^{154}$ In line with these considerations, a recent report demonstrated that Foxp $3^{+} \mathrm{T}$ cells can lose Foxp3 expression and convert into pathogenic Th17 cells in autoimmune arthritis. ${ }^{156}$ Importantly, such 'exFoxp3 ${ }^{+ \text {, }}$ cells were derived from Foxp3 ${ }^{+}$cells with a CD25 $5^{\text {lo }}$ phenotype, whereas CD25 ${ }^{\text {hi }}$ Foxp $^{+}$cells were stable and did not convert into Th17 cells in this model.

In fact, it is likely that a significant fraction of the Foxp $3^{+}$cells that convert into Th17 cells under inflammatory conditions are derived from the developmental intermediate described in the section above, and not from stable, suppressive Foxp $3^{+}$Treg cells. In accordance with this notion, it has become clear that Foxp3-expression alone is not a reliable marker for Treg function. It has been shown that Treg lineage stability and suppressive function requires a specific epigenetic modification: the hypomethylation of $\mathrm{CpG}$ motives within a number of Treg-specific signature loci in genes encoding for Foxp3, Ctla4, GITR, Eos and IL2ra (CD25). ${ }^{157-160}$ Thus, T cells possessing Foxp3 expression but not the Tregcell-type DNA hypomethylation pattern fail to exhibit sufficient Treg cell suppressive activity and instead secrete effector cytokines upon loss of Foxp3 expression. ${ }^{158,}$ 159, 161 Consequently, the Treg-cell-specific DNA hypomethylation pattern, together with Foxp3 expression, can be taken as a reliable marker for defining functional Treg cells. Data from our lab indicated that ex vivo purified Foxp $3^{+} \mathrm{ROR} \gamma \mathrm{t}^{+} \mathrm{T}$ cells from lymphoid organs and peripheral tissues such as the colonic lamina propria exhibit a hypomethylation pattern that is indicative for lineage stable and functional suppressive Treg cells (unpublished data).

There is growing evidence that Treg having undergone antigen-specific stimulation may differ significantly from their naive re-circulating counterparts in terms of activation status, migratory potential and regulatory function. ${ }^{162,163}$ Together with the notion that Treg having different origins or anatomical locations display distinct but specific gene expression profiles ${ }^{164}$, this has led to the discovery of different functional suppressive Treg subpopulations, termed 'effector' Treg lineages. ${ }^{165,}{ }^{166}$ Recent reports indicate that 
Foxp $3^{+}$Treg can upregulate the expression of transcription factors that are associated with the differentiation and function of effector $\mathrm{CD}^{+} \mathrm{T}$ cell lineages such as Th1 or Th2. In the context of Th1-mediated inflammation for example, Foxp3 ${ }^{+}$Treg can upregulate the Th1specific transcription factor T-bet, leading to the expression of CXCR3 and the accumulation of Foxp3 ${ }^{+} \mathrm{T}$-bet ${ }^{+}$Treg at sites of inflammation. This T-bet expression in Treg was shown to be essential for their homeostasis and function during type-1 inflammation. ${ }^{166}$ Likewise, the Th2associated transcription factor GATA3 was found to play an important role for Treg function, as it was shown that GATA3-deficient Treg display profound defects in peripheral homeostasis and suppressive function. ${ }^{167,} 168$ Effector Treg cells can express factors endowing them with specific tissue migration potential or enhanced suppressive capacity. ${ }^{169}$ Interestingly, our data show that ex vivo isolated Foxp $3^{+} \mathrm{ROR} \gamma \mathrm{t}^{+} \mathrm{T}$ cells express high levels of genes encoding for IRF4, Blimp-1, ICOS, GITR, Grzmb or CCR9 that were found to be upregulated in effector Treg and small intestine lamina propria Treg $\left({ }^{164,170}\right.$ and unpublished data). Together these findings suggests that the majority of Foxp $3^{+} \mathrm{ROR} \gamma \mathrm{t}^{+} \mathrm{T}$ cells observed in vivo represent a stable, suppressive effector Treg lineage, at least under homeostatic conditions. Although such cells may start to express certain levels of IL-17, it is unlikely that they will lose their suppressive function and convert into Th17 cells.

Similar to mice, IL-17-expressing Foxp ${ }^{+} \mathrm{T}$ cells have also been identified in humans. It was shown that Foxp $3^{+} \mathrm{CD}^{2} 5^{+}$(CD45RA $^{-} \mathrm{CCR} 6^{+}$memory) $\mathrm{T}$ cells isolated from peripheral blood of healthy donors can start to express IL-17 when activated ex vivo in the presence of proinflammatory cytokines like IL-6, IL-1 $\beta$ as well as IL-21 or IL-23, and expression of IL-17 came along with the expression of ROR $\mathrm{tt}^{171-173}$ Moreover, high levels of IL-17A producing Foxp $3^{+} \mathrm{RORyt}^{+} \mathrm{CD} 4^{+} \mathrm{T}$ cells were also isolated from human tonsils. ${ }^{173}$ Importantly, these cells exhibited suppressive capacity in vitro, indicating that they have Treg phenotype. ${ }^{171-173}$ In addition, enhanced frequencies of Foxp $3^{+} \mathrm{IL}-17^{+}$cells have been described in the colonic microenvironments of patients suffering from ulcerative colitis and colon carcinoma. ${ }^{174}$ Although these colonic Foxp $3^{+} \mathrm{IL}-17^{+}$cells were shown to be suppressive when tested ex vivo, it was speculated that they may contribute to inflammation and pathology due to their expression of IL-17. A recent report demonstrated that Foxp ${ }^{+} \mathrm{CD} 25^{+}$Treg cells expressing TLR2 can be converted into IL-17 ${ }^{+}$T cells by stimulation with TLR2 ligands in concert with IL6. These cells downregulated Foxp3-expression and displayed decreased suppressive capacity. ${ }^{175}$ In a follow up study, it was shown that Treg cells derived from patients with multiple sclerosis express enhanced levels of TLR2. It was therefore suggested that TLR2stimulation may contribute to reduced Treg function and a shift towards Th17 cells in this disease ${ }^{176}$ Conversion of Foxp $3^{+} \mathrm{CD} 25^{+}$cells into IL $17^{+}$Foxp3 $3^{-}$cells was reported when cells were stimulated by allogeneic APC, especially in the presence of proinflammatory cytokines such as IL-1 $\beta$, IL-23 and IL-21. ${ }^{177}$ Nevertheless, none of these studies assessed the 
epigenetic status of Treg-specific hypomethylated regions. It can therefore not be ruled out, that such converted Treg cells were derived from unstable Foxp3-expressing subpopulations. Of note, it was shown that human Th17 cells differentiate from a Foxp3-expressing precursor ${ }^{178}$, suggesting that similar to what has been described for mouse cells above, human Th17 development is also marked by a Foxp $3^{+}$intermediate stage.

\section{Foxp $^{+}$Treg can inhibit Th17 cells}

As described above, Treg and Th17 cells arise in the periphery via a common Foxp ${ }^{+} \mathrm{ROR} \gamma \mathrm{t}^{+}$ intermediate. Thus, the competition of Treg with Th17 cells for their reciprocal development from this common precursor can already be seen as a way to control Th17 or Treg development, respectively. In the intestine for example, nutrition-derived factors like retinoic acid (RA) $)^{179-181}$ or short-chain fatty acids produced by the commensal microbiota will shift the balance towards the induction of Treg cells under normal homeostatic conditions. ${ }^{182-184}$ This balance can however be modulated by inflammatory factors. In a recent report it was shown that IL-1 $\beta$ can override the RA-mediated Treg induction by increasing the amplitude and duration of STAT3 phosphorylation. This led to an altered balance in the binding of STAT3 and STAT5 to shared consensus sequences in developing T cells and consequently shifted the balance towards Th17 induction. ${ }^{185}$

Nevertheless, beside this developmental competition, Treg cells can also directly inhibit the function of Th17 cells (Figure 1a). Recently, it has been described that Th17 cells express the IL-10 receptor on their surface. ${ }^{186,187} \mathrm{IL}-10$ secreted by Foxp3 ${ }^{+}$as well as Foxp3 ${ }^{-}$ Tr1 cells selectively inhibited Th17 cell proliferation in vitro and suppress Th17 cell-related T cell transfer colitis in vivo. ${ }^{187}$ In addition, it was reported that IL-10 itself endows Foxp3 ${ }^{+}$Treg with the ability to suppress pathogenic Th17 responses. ${ }^{186}$ Interestingly, STAT3-activation downstream of IL10R signaling in Treg was shown to be crucial for their ability to suppress Th17 cell responses in vivo, probably by the ability of STAT3 to amplify the IL-10 expression by Treg themselves. ${ }^{186}$ Since effector Treg cells can express high amounts of IL-10, these cells should exhibit a strong suppressive effect on Th17 cells. Yet, effector Treg cells may restrain the function of Th17 also via other mechanisms. A recent publication described Treg cells expressing the coinhibitory molecule TIGIT as potent inhibitors of Th17 and Th1, but not Th2 responses. ${ }^{188}$ It was demonstrated that ligation of TIGIT induces this population to express fibrinogen-like protein 2 (Fgl2), which suppressed the expansion of effector $\mathrm{T}$ cells in a manner independent of IL-10. In addition, Treg may also indirectly influence Th17 cell response via tolerizing dendritic cells. In that respect, it has been shown that TIGIT can interact with its ligand on DC to induce IL-10 and reduce IL-12 production from these cells. ${ }^{189}$ TIGIT-induced IL-10 was shown to suppress expression of both IL-12p35 and IL-12p40, the 
subunit shared with IL-23. Hence, Treg may directly suppress both IL-12 and IL-23 production from DC and thereby inhibit the development of both Th1 and Th17 responses.

It has been speculated that the expression of lineage-specific transcription factors like T-bet or Gata3 drives the generation of effector Treg that are specifically suited to regulate immune responses mediated by their corresponding conventional effector $\mathrm{CD}^{+} \mathrm{T}$ cell lineages (see section on Function and stability of Foxp $^{+} \mathrm{T}$ cells that express the Th17 molecules ROR $\gamma \mathrm{t}$ and IL-17). It is therefore tempting to speculate that Foxp $3^{+} \mathrm{ROR} \gamma \mathrm{t}^{+}$Treg, due to similar tissue location or migratory potential, may exhibit specific suppressive function on Th17 cells. However, the potential of the Foxp $3^{+} \mathrm{ROR} \gamma \mathrm{t}^{+}$Treg subpopulation to specifically suppress Th17 or other T helper cell responses remains to be investigated.

\section{Treg can promote Th17 induction}

Although it is clear that Treg cells and Th17 cells have opposing functions, there is now ample evidence that Treg cells can also promote the differentiation of Th17 cells (Figure 1b). It was already shown in one of the first reports on Th17 cells that the presence of Treg can stimulate Th17 development in vitro. Veldhoen et al. demonstrated that the production of TGF- $\beta 1$ by Treg contributed to the Th17 development in the in vitro culture system. ${ }^{12}$ However, whether Treg-produced TGF- $\beta 1$ promotes Th17 cell induction in vivo, especially under conditions of pathogen infection, remains unclear. Given that Th17 cell development is induced upon low levels of TGF- $\beta 1$, but is rather impaired under higher concentrations of TGF- $\beta 1$ in vitro ${ }^{147}$, the maintenance of a proper low level of TGF- $\beta 1$ by Treg in the local niche in vivo would be a critical step for Th17 cell development. Thus, although Treg may contribute to Th17 development in vitro by secreting TGF- $\beta 1$, recent results from in vivo studies suggested that Treg-produced TGF- $\beta 1$ does not influence in vivo Th17 cell development. ${ }^{190,191}$

In vivo, Treg cells can also favour the accumulation of Th17 cells by inhibiting the development of Th1 or Th1-like 'exTh17' cells. This feature of Treg has been observed in context of co-transfer of Treg cells together with naïve $T$ cells into immunodeficient RAGdeficient animals, the classic transfer colitis model. ${ }^{192}$ Intriguingly, the transfer of Treg not only inhibited the development of classic Th1 T cells, but also increased the amount of IL-17 producing effector $T$ cells in the colon of the mice by inhibiting the transition of Th17 cells into Th1-like 'exTh17 cells'. ${ }^{193}$ It is thus possible that besides inhibiting the accumulation of pathogenic Th1 and 'exTh17 cell' in this model, Treg protect the mice from intestinal immunopathology by favouring the presence of IL-17 producing cells with beneficial effects on intestinal barrier function and epithelial repair mechanisms (see section on the role of Th17 cells in infection and inflammation). 
In addition to TGF- $\beta$, IL-2 plays an important role for the differentiateion of pTreg. ${ }^{194}$ Although tTreg do not require IL-2 for their development, both tTreg and pTreg rely on IL-2 for the survival expansion. ${ }^{195}$ Due to the expression of high levels of CD25 on their surface, Treg possess the trimeric high-affinity IL-2 receptor containing CD25, CD122 and CD132, whereas other effector T cells have dimeric low-affinity IL-2 receptor comprising CD122 and CD132. ${ }^{196}$ As a result, Treg have an advantage over effector $T$ cells in competing for the common $\mathrm{T}$ cell survival factor IL-2, and thus inhibiting effector $\mathrm{T}$ cell responses by depriving them of IL-2. Importantly, IL-2 induces phosphorylation of STAT5 in developing Th17 cells, which in turn blocks phosphorylated-STAT3 mediated induction of $1 / 17 a$ and Rorc transcriptions. Thus, presence of IL-2 can directly impair Th17 cell development. ${ }^{197}$ Several reports have shown recently that Treg can indeed promote a Th17 cell response via consumption of IL-2. ${ }^{190,198,199}$ Using the Foxp3-luci-DTR model ${ }^{138}$, Chen et al. showed that depletion of Foxp3 ${ }^{+}$Treg by diphtheria toxin (DT) decreased the frequency of antigen-specific Th17 cells in draining lymph nodes and blood. ${ }^{190}$ They further showed that the Th17-inducing ability of Treg is not attributed to their secretion of TGF- $\beta 1$, but due to their IL-2 consumption. Pandiyan and coworkers also found that Treg promoted the differentiation of $\mathrm{CD} 4^{+}$naïve $\mathrm{T}$ cells into Th17 cells under Th17-polarizing condition in vitro and upon C. albicans infection in vivo. ${ }^{199}$ Using IL-2-deficient TCR transgenic mice, they further illustrated that Treg-mediated Th17 cell development depended on the consumption of IL-2 by Treg. Moreover, they confirmed the protective effect of Treg co-transfer with $\mathrm{CD}^{+}$naïve T cells into Rag2 ${ }^{-/}$mice on the subsequent $C$. albicans infection, whereas recipients receiving only $C D 4^{+}$naïve $T$ cells succumbed to this infection as a result of the insufficient induction of a Th17 cell response. In agreement with these previous studies, a study from our lab showed that Treg promote Th17 cell response against $C$. rodentium infection in the intestine. ${ }^{200}$ Using the Foxp3-DTR DEREG mouse model ${ }^{137}$, we could demonstrate that depletion of Foxp3 ${ }^{+}$Treg by administration of DT resulted in enhanced susceptibility towards $C$. rodentium infection due to an impaired local colonic Th17 cell response. ${ }^{200}$ Interestingly, the failure to develop a sufficient Th17 cell response after Treg depletion resulted in decreased inflammation and immunopathology in the colon of the mice. Nevertheless, reduced Th17 induction and the consequent defect in neutrophil recruitment also led to enhanced systemic dissemination of the pathogen and eventually to higher mortality. This demonstrates that Treg can help to establish an effective Th17 response in the gut environment, although this comes at the cost of immunopathology at the site of infection. Blockade of IL-2 in Treg-depleted mice using neutralizing anti-IL-2 antibody restored colonic Th17 cell induction after $C$. rodentium infection. However, neutralization of IL-2 did not restore the Th17 response in term of absolute numbers of IL-17-producing $\mathrm{T}$ cells in the colon. This suggests that even if IL-2 does inhibit initial Th17 induction, some levels of this cytokine are required for later 
expansion of these cells. In line with this, it has also been described that IL-2 facilitates the expansion of committed Th17 cells. ${ }^{201}$ Together, these data indicate that by consuming IL-2, Treg can support the initial induction of Th17 cells. However, this mechanism may not play a role for the subsequent expansion and maintenance of Th17 cells. ${ }^{190}$

By their ability to modulate IL-2 levels, Treg have been shown to be also involved in negatively regulating natural killer (NK) cells expansion, activation, maturation and function in vivo. $^{202,203}$ Gasteiger and coworkers have shown that Treg compete with NK cells for IL-2. In their system, depletion of Treg lead to maturation of NKs and IL-2 treatment boosted cytotoxicity of NK cells. Moreover, a recent study also illustrated that Treg, by consuming IL2, promote germinal center (GC) formation during influenza virus infection. ${ }^{191}$ As a result of Treg depletion, accumulation of IL-2 impaired the differentiation of follicular $\mathrm{T}$ helper cells (Tfh), and impaired the protective GC B cell response against influenza viral infection. ${ }^{191}$ Therefore, it seems that Treg-mediated consumption of IL-2 represents a general mechanism by which Treg can regulate multiple immune cell responses in vivo.

\section{Concluding remarks}

As two important immune cell lineages, Treg and Th17 cells are involved in multiple physiological events. Treg are regarded as immune regulator that prevent an excessive immune response, while Th17 cells are normally involved in the defence against extracellular bacterial and fungal infection. However both, excessive Treg or Th17 cell responses can threat the health of the host. Enhanced Treg suppression may facilitate tumorigenesis and can be used by pathogens to escape the immune surveillance system, whereas uncontrolled Th17 cell responses are involved in inflammation and autoimmune disease. According to the model of the immunological balance, a fine-tuned balance between Treg and Th17 cells would not only be a critical prerequisite for healthy homeostasis, but also direct the outcome of immune responses. Regarding the close interconnection of Treg/Th17 developmental and functional cues, direct modulation of the immunological balance between Treg and Th17 cells represents a promising option for immune therapy.

Factors that influence the regulation of the Treg/Th17 balance thus represent potential targets for therapeutic intervention. Recently, the field of immune metabolism has gained increasing attention in immunological research. Manipulation of the intermediate cellular metabolism such as glycolysis, fatty acid or the mitochondrial metabolism can be achieved using small molecule inhibitors of key regulatory enzymes of these processes. Direct manipulation of the cellular fatty acid metabolism for example can shift the balance between Th17 and Treg development ${ }^{28}$, but many other metabolic checkpoints may be exploited as targets to control the Treg/Th17 balance. ${ }^{204}$ 
Yet, our increasing knowledge on the relationship between Treg and Th17 cells that we have reviewed here, suggest multiple layers of complexity. As we have shown, Treg cells not only suppress the function of Th17 cells, but can also support their development by the uptake of IL-2. In addition, the inhibition of Th17 cells may not always be beneficial, as has been demonstrated in the context of intestinal inflammation and epithelial repair. Finally, features of Th17 cells such as the expression of ROR $\gamma \mathrm{t}$ in specific populations of effector Treg cells may be important for their optimal suppressive function. Although the exact role of ROR $\gamma \mathrm{t}$ in Foxp3 ${ }^{+} \mathrm{ROR} \mathrm{t}^{+}$remains to be assessed, it should be taken into account that approaches aiming on the inhibition of ROR $\gamma$ t function will not only impact on Th17 cells, but may also affect such effector Treg cells.

\section{Acknowledgements}

This work was supported by a grant from the Deutsche Forschungsgemeinschaft (DFG KFO250). A part of this work is content of the 'habilitation' thesis of M.L. The authors would like to thank Peyman Ghorbani for critical reading of the manuscript. 


\section{Figure legend}

Figure1. Dual roles of Treg in regulating Th17 cell response. (a) Treg can inhibit the Th17 cell response. Under homeostatic condition, naïve T cells differentiate into pTreg rather than Th17 cells in the periphery. pTreg together with tTreg may also tolerate dendritic cells that trigger Th17 cell induction. Established effector (e)Treg such as $\mathrm{TIGIT}^{+}$or stable Foxp $3^{+} \mathrm{ROR} \gamma \mathrm{t}^{+} \mathrm{T}$ cells can produce factors like IL-10 or Fibrinogen like protein-2 that inhibit Th17 cells. (b) Treg can contribute to Th17 cell response. By consumption of local IL-2, Treg release the inhibitory effect of high-level of IL-2 on Th17 cell induction and promote Th17 cell differentiation. In addition, TGF- $\beta$ production by Treg may also lead to enhanced Th17 induction. Under inflammatory condition, Treg may start to produce IL-17 and may even lose Foxp3 expression and convert into pathogenic Th17 cells. 


\section{References}

1. Harrington LE, Hatton RD, Mangan PR, Turner H, Murphy TL, Murphy KM et al. Interleukin 17producing CD4+ effector T cells develop via a lineage distinct from the T helper type 1 and 2 lineages. Nat Immunol 2005; 6(11): 1123-1132.

2. Langrish $\mathrm{CL}$, Chen $\mathrm{Y}$, Blumenschein WM, Mattson J, Basham B, Sedgwick JD et al. IL-23 drives a pathogenic $T$ cell population that induces autoimmune inflammation. J Exp Med 2005; 201(2): 233-240.

3. Park H, Li Z, Yang XO, Chang SH, Nurieva R, Wang YH et al. A distinct lineage of CD4 T cells regulates tissue inflammation by producing interleukin 17. Nat Immunol 2005; 6(11): 1133-1141.

4. Aarvak T, Chabaud M, Miossec P, Natvig JB. IL-17 is produced by some proinflammatory Th1/Th0 cells but not by Th2 cells. J Immunol 1999; 162(3): 1246-1251.

5. Infante-Duarte C, Horton HF, Byrne MC, Kamradt T. Microbial lipopeptides induce the production of IL-17 in Th cells. J Immunol 2000; 165(11): 6107-6115.

6. Cua DJ, Tato CM. Innate IL-17-producing cells: the sentinels of the immune system. Nat Rev Immunol 2010; 10(7): 479-489.

7. Michel ML, Mendes-da-Cruz D, Keller AC, Lochner M, Schneider E, Dy M et al. Critical role of ROR-gammat in a new thymic pathway leading to IL-17-producing invariant NKT cell differentiation. Proc Natl Acad Sci U S A 2008; 105(50): 19845-19850.

8. Eberl G, Colonna M, Di Santo JP, McKenzie AN. Innate lymphoid cells. Innate lymphoid cells: a new paradigm in immunology. Science 2015; 348(6237): aaa6566.

9. Cua DJ, Sherlock J, Chen Y, Murphy CA, Joyce B, Seymour B et al. Interleukin-23 rather than interleukin-12 is the critical cytokine for autoimmune inflammation of the brain. Nature 2003; 421(6924): 744-748.

10. Bettelli E, Carrier Y, Gao W, Korn T, Strom TB, Oukka M et al. Reciprocal developmental pathways for the generation of pathogenic effector TH17 and regulatory T cells. Nature 2006; 441(7090): 235-238.

11. Mangan PR, Harrington LE, O'Quinn DB, Helms WS, Bullard DC, Elson CO et al. Transforming growth factor-beta induces development of the $T(H) 17$ lineage. Nature 2006; 441(7090): 231234.

12. Veldhoen M, Hocking RJ, Atkins CJ, Locksley RM, Stockinger B. TGFbeta in the context of an inflammatory cytokine milieu supports de novo differentiation of IL-17-producing $T$ cells. Immunity 2006; 24(2): 179-189.

13. Durant L, Watford WT, Ramos HL, Laurence A, Vahedi G, Wei L et al. Diverse targets of the transcription factor STAT3 contribute to T cell pathogenicity and homeostasis. Immunity 2010; 32(5): 605-615.

14. Ortiz MA, Piedrafita FJ, Pfahl M, Maki R. TOR: a new orphan receptor expressed in the thymus that can modulate retinoid and thyroid hormone signals. Mol Endocrinol 1995; 9(12): 16791691.

15. Guo J, Hawwari A, Li H, Sun Z, Mahanta SK, Littman DR et al. Regulation of the TCRalpha repertoire by the survival window of CD4(+)CD8(+) thymocytes. Nat Immunol 2002; 3(5): 469476.

16. He YW, Beers C, Deftos ML, Ojala EW, Forbush KA, Bevan MJ. Down-regulation of the orphan nuclear receptor ROR gamma t is essential for T lymphocyte maturation. J Immunol 2000; 164(11): 5668-5674. 
17. Sun Z, Unutmaz D, Zou YR, Sunshine MJ, Pierani A, Brenner-Morton S et al. Requirement for RORgamma in thymocyte survival and lymphoid organ development. Science 2000; 288(5475): 2369-2373.

18. Villey I, de Chasseval R, de Villartay JP. RORgammaT, a thymus-specific isoform of the orphan nuclear receptor RORgamma / TOR, is up-regulated by signaling through the pre-T cell receptor and binds to the TEA promoter. Eur J Immunol 1999; 29(12): 4072-4080.

19. Eberl G, Marmon S, Sunshine MJ, Rennert PD, Choi Y, Littman DR. An essential function for the nuclear receptor RORgamma(t) in the generation of fetal lymphoid tissue inducer cells. Nat Immunol 2004; 5(1): 64-73.

20. Cording S, Medvedovic J, Cherrier M, Eberl G. Development and regulation of RORgammat(+) innate lymphoid cells. FEBS Lett 2014; 588(22): 4176-4181.

21. Diefenbach A, Colonna M, Koyasu S. Development, differentiation, and diversity of innate lymphoid cells. Immunity 2014; 41(3): 354-365.

22. Ivanov, II, McKenzie BS, Zhou L, Tadokoro CE, Lepelley A, Lafaille JJ et al. The orphan nuclear receptor RORgammat directs the differentiation program of proinflammatory IL-17+ $\mathrm{T}$ helper cells. Cell 2006; 126(6): 1121-1133.

23. Ciofani M, Madar A, Galan C, Sellars M, Mace K, Pauli F et al. A validated regulatory network for Th17 cell specification. Cell 2012; 151(2): 289-303.

24. Korn T, Oukka M, Kuchroo V, Bettelli E. Th17 cells: effector T cells with inflammatory properties. Semin Immunol 2007; 19(6): 362-371.

25. Nurieva R, Yang XO, Martinez G, Zhang Y, Panopoulos AD, Ma L et al. Essential autocrine regulation by IL-21 in the generation of inflammatory T cells. Nature 2007; 448(7152): 480-483.

26. Chung Y, Chang SH, Martinez GJ, Yang XO, Nurieva R, Kang HS et al. Critical regulation of early Th17 cell differentiation by interleukin-1 signaling. Immunity 2009; 30(4): 576-587.

27. Gulen MF, Kang Z, Bulek K, Youzhong W, Kim TW, Chen Y et al. The receptor SIGIRR suppresses Th17 cell proliferation via inhibition of the interleukin-1 receptor pathway and mTOR kinase activation. Immunity 2010; 32(1): 54-66.

28. Berod L, Friedrich C, Nandan A, Freitag J, Hagemann S, Harmrolfs $\mathrm{K}$ et al. De novo fatty acid synthesis controls the fate between regulatory T and T helper 17 cells. Nat Med 2014; 20(11): 1327-1333.

29. Michalek RD, Gerriets VA, Jacobs SR, Macintyre AN, Maclver NJ, Mason EF et al. Cutting edge: distinct glycolytic and lipid oxidative metabolic programs are essential for effector and regulatory CD4+ T cell subsets. J Immunol 2011; 186(6): 3299-3303.

30. Powell JD, Pollizzi KN, Heikamp EB, Horton MR. Regulation of immune responses by mTOR. Annu Rev Immunol 2012; 30: 39-68.

31. Dang EV, Barbi J, Yang HY, Jinasena D, Yu H, Zheng Y et al. Control of $\mathrm{T}(\mathrm{H}) 17 / \mathrm{T}(\mathrm{reg})$ balance by hypoxia-inducible factor 1 . Cell 2011; 146(5): 772-784.

32. Shi LZ, Wang R, Huang G, Vogel P, Neale G, Green DR et al. HIF1alpha-dependent glycolytic pathway orchestrates a metabolic checkpoint for the differentiation of TH17 and Treg cells. J Exp Med 2011; 208(7): 1367-1376.

33. Gutcher I, Donkor MK, Ma Q, Rudensky AY, Flavell RA, Li MO. Autocrine transforming growth factor-beta1 promotes in vivo Th17 cell differentiation. Immunity 2011; 34(3): 396-408.

34. Li MO, Wan YY, Flavell RA. T cell-produced transforming growth factor-beta1 controls $\mathrm{T}$ cell tolerance and regulates Th1- and Th17-cell differentiation. Immunity 2007; 26(5): 579-591. 
35. Veldhoen M, Hocking RJ, Flavell RA, Stockinger B. Signals mediated by transforming growth factor-beta initiate autoimmune encephalomyelitis, but chronic inflammation is needed to sustain disease. Nat Immunol 2006; 7(11): 1151-1156.

36. Das J, Ren G, Zhang L, Roberts Al, Zhao X, Bothwell AL et al. Transforming growth factor beta is dispensable for the molecular orchestration of Th17 cell differentiation. J Exp Med 2009; 206(11): 2407-2416.

37. Ghoreschi K, Laurence A, Yang XP, Tato CM, McGeachy MJ, Konkel JE et al. Generation of pathogenic $T(H) 17$ cells in the absence of TGF-beta signalling. Nature 2010; 467(7318): 967971.

38. McGeachy MJ, Bak-Jensen KS, Chen Y, Tato CM, Blumenschein W, McClanahan T et al. TGFbeta and IL- 6 drive the production of IL-17 and IL-10 by T cells and restrain $T(H)-17$ cellmediated pathology. Nat Immunol 2007; 8(12): 1390-1397.

39. Haines CJ, Chen Y, Blumenschein WM, Jain R, Chang C, Joyce-Shaikh B et al. Autoimmune memory $\mathrm{T}$ helper 17 cell function and expansion are dependent on interleukin-23. Cell Rep 2013; 3(5): 1378-1388.

40. McGeachy MJ, Chen Y, Tato CM, Laurence A, Joyce-Shaikh B, Blumenschein WM et al. The interleukin 23 receptor is essential for the terminal differentiation of interleukin 17-producing effector T helper cells in vivo. Nat Immunol 2009; 10(3): 314-324.

41. Esplugues E, Huber S, Gagliani N, Hauser AE, Town T, Wan YY et al. Control of TH17 cells occurs in the small intestine. Nature 2011; 475(7357): 514-518.

42. Heinemann C, Heink S, Petermann F, Vasanthakumar A, Rothhammer V, Doorduijn E et al. IL27 and IL-12 oppose pro-inflammatory IL-23 in CD4+ T cells by inducing Blimp1. Nat Commun 2014; 5: 3770.

43. Lee $\mathrm{Y}$, Awasthi A, Yosef N, Quintana FJ, Xiao S, Peters A et al. Induction and molecular signature of pathogenic TH17 cells. Nat Immunol 2012; 13(10): 991-999.

44. Hirota K, Duarte JH, Veldhoen M, Hornsby E, Li Y, Cua DJ et al. Fate mapping of IL-17producing T cells in inflammatory responses. Nat Immunol 2011; 12(3): 255-263.

45. Lee YK, Turner H, Maynard CL, Oliver JR, Chen D, Elson CO et al. Late developmental plasticity in the T helper 17 lineage. Immunity 2009; 30(1): 92-107.

46. Yang $\mathrm{Y}$, Weiner $\mathrm{J}$, Liu $\mathrm{Y}$, Smith AJ, Huss $\mathrm{DJ}$, Winger $\mathrm{R}$ et al. T-bet is essential for encephalitogenicity of both Th1 and Th17 cells. J Exp Med 2009; 206(7): 1549-1564.

47. Ahern PP, Schiering C, Buonocore S, McGeachy MJ, Cua DJ, Maloy KJ et al. Interleukin-23 drives intestinal inflammation through direct activity on T cells. Immunity 2010; 33(2): 279-288.

48. Globig AM, Hennecke N, Martin B, Seidl M, Ruf G, Hasselblatt P et al. Comprehensive intestinal T helper cell profiling reveals specific accumulation of IFN-gamma+IL-17+coproducing CD4+ T cells in active inflammatory bowel disease. Inflamm Bowel Dis 2014; 20(12): 2321-2329.

49. Hue S, Ahern P, Buonocore S, Kullberg MC, Cua DJ, McKenzie BS et al. Interleukin-23 drives innate and T cell-mediated intestinal inflammation. J Exp Med 2006; 203(11): 2473-2483.

50. Kullberg MC, Jankovic D, Feng CG, Hue S, Gorelick PL, McKenzie BS et al. IL-23 plays a key role in Helicobacter hepaticus-induced T cell-dependent colitis. J Exp Med 2006; 203(11): 24852494.

51. Bending D, Newland S, Krejci A, Phillips JM, Bray S, Cooke A. Epigenetic changes at II12rb2 and Tbx21 in relation to plasticity behavior of Th17 cells. J Immunol 2011; 186(6): 3373-3382. 
52. Mukasa R, Balasubramani A, Lee YK, Whitley SK, Weaver BT, Shibata $Y$ et al. Epigenetic instability of cytokine and transcription factor gene loci underlies plasticity of the Thelper 17 cell lineage. Immunity 2010; 32(5): 616-627.

53. Wei G, Wei L, Zhu J, Zang C, Hu-Li J, Yao Z et al. Global mapping of H3K4me3 and H3K27me3 reveals specificity and plasticity in lineage fate determination of differentiating CD4+ $T$ cells. Immunity 2009; 30(1): 155-167.

54. Bending D, De la Pena H, Veldhoen M, Phillips JM, Uyttenhove C, Stockinger B et al. Highly purified Th17 cells from BDC2.5NOD mice convert into Th1-like cells in NOD/SCID recipient mice. J Clin Invest 2009; 119(3): 565-572.

55. Martin-Orozco N, Chung Y, Chang SH, Wang YH, Dong C. Th17 cells promote pancreatic inflammation but only induce diabetes efficiently in lymphopenic hosts after conversion into Th1 cells. Eur J Immunol 2009; 39(1): 216-224.

56. Croxford AL, Kurschus FC, Waisman A. Cutting edge: an IL-17F-CreEYFP reporter mouse allows fate mapping of Th17 cells. J Immunol 2009; 182(3): 1237-1241.

57. Gagliani N, Vesely MC, Iseppon A, Brockmann L, Xu H, Palm NW et al. Th17 cells transdifferentiate into regulatory T cells during resolution of inflammation. Nature 2015.

58. Hirota K, Turner JE, Villa M, Duarte JH, Demengeot J, Steinmetz OM et al. Plasticity of Th17 cells in Peyer's patches is responsible for the induction of T cell-dependent IgA responses. Nat Immunol 2013; 14(4): 372-379.

59. Muranski P, Borman ZA, Kerkar SP, Klebanoff CA, Ji Y, Sanchez-Perez L et al. Th17 cells are long lived and retain a stem cell-like molecular signature. Immunity 2011; 35(6): 972-985.

60. Kryczek I, Zhao E, Liu Y, Wang Y, Vatan L, Szeliga W et al. Human TH17 cells are long-lived effector memory cells. Sci Transl Med 2011; 3(104): 104ra100.

61. Lochner M, Peduto L, Cherrier M, Sawa S, Langa F, Varona R et al. In vivo equilibrium of proinflammatory IL-17+ and regulatory IL-10+ Foxp3+ RORgamma t+ T cells. J Exp Med 2008; 205(6): 1381-1393.

62. Gaboriau-Routhiau V, Rakotobe S, Lecuyer E, Mulder I, Lan A, Bridonneau C et al. The key role of segmented filamentous bacteria in the coordinated maturation of gut helper $T$ cell responses. Immunity 2009; 31(4): 677-689.

63. Ivanov, II, Atarashi K, Manel N, Brodie EL, Shima T, Karaoz U et al. Induction of intestinal Th17 cells by segmented filamentous bacteria. Cell 2009; 139(3): 485-498.

64. Lochner M, Berard M, Sawa S, Hauer S, Gaboriau-Routhiau V, Fernandez TD et al. Restricted microbiota and absence of cognate TCR antigen leads to an unbalanced generation of Th17 cells. J Immunol 2011; 186(3): 1531-1537.

65. Goto Y, Panea C, Nakato G, Cebula A, Lee C, Diez MG et al. Segmented filamentous bacteria antigens presented by intestinal dendritic cells drive mucosal Th17 cell differentiation. Immunity 2014; 40(4): 594-607.

66. Yang $\mathrm{Y}$, Torchinsky MB, Gobert $\mathrm{M}$, Xiong $\mathrm{H}, \mathrm{Xu} \mathrm{M}$, Linehan $\mathrm{JL}$ et al. Focused specificity of intestinal TH17 cells towards commensal bacterial antigens. Nature 2014; 510(7503): 152-156.

67. Talham GL, Jiang HQ, Bos NA, Cebra JJ. Segmented filamentous bacteria are potent stimuli of a physiologically normal state of the murine gut mucosal immune system. Infect Immun 1999; 67(4): 1992-2000.

68. Atarashi K, Nishimura J, Shima T, Umesaki $\mathrm{Y}$, Yamamoto $\mathrm{M}$, Onoue $\mathrm{M}$ et al. ATP drives lamina propria $\mathrm{T}(\mathrm{H}) 17$ cell differentiation. Nature 2008; 455(7214): 808-812. 
69. Ivanov, II, Frutos Rde L, Manel N, Yoshinaga K, Rifkin DB, Sartor RB et al. Specific microbiota direct the differentiation of IL-17-producing T-helper cells in the mucosa of the small intestine. Cell Host Microbe 2008; 4(4): 337-349.

70. Lewis KL, Caton ML, Bogunovic M, Greter M, Grajkowska LT, Ng D et al. Notch2 receptor signaling controls functional differentiation of dendritic cells in the spleen and intestine. Immunity 2011; 35(5): 780-791.

71. Persson EK, Uronen-Hansson $\mathrm{H}$, Semmrich $\mathrm{M}$, Rivollier $\mathrm{A}$, Hagerbrand $\mathrm{K}$, Marsal $\mathrm{J}$ et al. IRF4 transcription-factor-dependent $\mathrm{CD} 103(+) \mathrm{CD} 11 \mathrm{~b}(+)$ dendritic cells drive mucosal T helper 17 cell differentiation. Immunity 2013; 38(5): 958-969.

72. Satpathy AT, Briseno CG, Lee JS, Ng D, Manieri NA, Kc W et al. Notch2-dependent classical dendritic cells orchestrate intestinal immunity to attaching-and-effacing bacterial pathogens. Nat Immunol 2013; 14(9): 937-948.

73. Schlitzer A, McGovern N, Teo P, Zelante T, Atarashi K, Low D et al. IRF4 transcription factordependent CD11b+ dendritic cells in human and mouse control mucosal IL-17 cytokine responses. Immunity 2013; 38(5): 970-983.

74. Welty NE, Staley C, Ghilardi N, Sadowsky MJ, Igyarto BZ, Kaplan DH. Intestinal lamina propria dendritic cells maintain T cell homeostasis but do not affect commensalism. J Exp Med 2013; 210(10): 2011-2024.

75. Cerovic V, Houston SA, Scott CL, Aumeunier A, Yrlid U, Mowat AM et al. Intestinal CD103(-) dendritic cells migrate in lymph and prime effector T cells. Mucosal Immunol 2013; 6(1): 104113.

76. Fujimoto K, Karuppuchamy $\mathrm{T}$, Takemura N, Shimohigoshi M, Machida T, Haseda $\mathrm{Y}$ et al. A new subset of CD103+CD8alpha+ dendritic cells in the small intestine expresses TLR3, TLR7, and TLR9 and induces Th1 response and CTL activity. J Immunol 2011; 186(11): 6287-6295.

77. Uematsu S, Fujimoto K, Jang MH, Yang BG, Jung YJ, Nishiyama $M$ et al. Regulation of humoral and cellular gut immunity by lamina propria dendritic cells expressing Toll-like receptor 5 . Nat Immunol 2008; 9(7): 769-776.

78. Kinnebrew MA, Buffie CG, Diehl GE, Zenewicz LA, Leiner I, Hohl TM et al. Interleukin 23 production by intestinal $\mathrm{CD} 103(+) \mathrm{CD} 11 \mathrm{~b}(+)$ dendritic cells in response to bacterial flagellin enhances mucosal innate immune defense. Immunity 2012; 36(2): 276-287.

79. Shaw MH, Kamada N, Kim YG, Nunez G. Microbiota-induced IL-1beta, but not IL-6, is critical for the development of steady-state TH17 cells in the intestine. J Exp Med 2012; 209(2): 251-258.

80. Quintana FJ, Basso AS, Iglesias AH, Korn T, Farez MF, Bettelli E et al. Control of T(reg) and $\mathrm{T}(\mathrm{H}) 17$ cell differentiation by the aryl hydrocarbon receptor. Nature 2008; 453(7191): 65-71.

81. Veldhoen M, Hirota K, Westendorf AM, Buer J, Dumoutier L, Renauld JC et al. The aryl hydrocarbon receptor links TH17-cell-mediated autoimmunity to environmental toxins. Nature 2008; 453(7191): 106-109.

82. Nakahama T, Kimura A, Nguyen NT, Chinen I, Hanieh H, Nohara $\mathrm{K}$ et al. Aryl hydrocarbon receptor deficiency in $\mathrm{T}$ cells suppresses the development of collagen-induced arthritis. Proc Natl Acad Sci U S A 2011; 108(34): 14222-14227.

83. Quintana FJ, Murugaiyan G, Farez MF, Mitsdoerffer M, Tukpah AM, Burns EJ et al. An endogenous aryl hydrocarbon receptor ligand acts on dendritic cells and $T$ cells to suppress experimental autoimmune encephalomyelitis. Proc Natl Acad Sci U S A 2010; 107(48): 2076820773.

84. Li Y, Innocentin S, Withers DR, Roberts NA, Gallagher AR, Grigorieva EF et al. Exogenous stimuli maintain intraepithelial lymphocytes via aryl hydrocarbon receptor activation. Cell 2011; 147(3): 629-640. 
85. Qiu J, Guo X, Chen ZM, He L, Sonnenberg GF, Artis D et al. Group 3 innate lymphoid cells inhibit T-cell-mediated intestinal inflammation through aryl hydrocarbon receptor signaling and regulation of microflora. Immunity 2013; 39(2): 386-399.

86. Khader SA, Gaffen SL, Kolls JK. Th17 cells at the crossroads of innate and adaptive immunity against infectious diseases at the mucosa. Mucosal Immunol 2009; 2(5): 403-411.

87. Kolls JK, Khader SA. The role of Th17 cytokines in primary mucosal immunity. Cytokine Growth Factor Rev 2010; 21(6): 443-448.

88. Pappu R, Rutz S, Ouyang W. Regulation of epithelial immunity by IL-17 family cytokines. Trends Immunol 2012; 33(7): 343-349.

89. Pickert G, Neufert C, Leppkes M, Zheng Y, Wittkopf N, Warntjen M et al. STAT3 links IL-22 signaling in intestinal epithelial cells to mucosal wound healing. J Exp Med 2009; 206(7): 14651472.

90. Ouyang $\mathrm{W}$, Kolls JK, Zheng $\mathrm{Y}$. The biological functions of $\mathrm{T}$ helper 17 cell effector cytokines in inflammation. Immunity 2008; 28(4): 454-467.

91. Pelletier M, Maggi L, Micheletti A, Lazzeri E, Tamassia N, Costantini C et al. Evidence for a cross-talk between human neutrophils and Th17 cells. Blood 2009; 115(2): 335-343.

92. Ye P, Rodriguez FH, Kanaly S, Stocking KL, Schurr J, Schwarzenberger $\mathrm{P}$ et al. Requirement of interleukin 17 receptor signaling for lung CXC chemokine and granulocyte colony-stimulating factor expression, neutrophil recruitment, and host defense. J Exp Med 2001; 194(4): 519-527.

93. Milner JD, Sandler NG, Douek DC. Th17 cells, Job's syndrome and HIV: opportunities for bacterial and fungal infections. Curr Opin HIV AIDS 2010; 5(2): 179-183.

94. Paulson ML, Freeman AF, Holland SM. Hyper IgE syndrome: an update on clinical aspects and the role of signal transducer and activator of transcription 3. Curr Opin Allergy Clin Immunol 2008; 8(6): 527-533.

95. Conti HR, Shen F, Nayyar N, Stocum E, Sun JN, Lindemann MJ et al. Th17 cells and IL-17 receptor signaling are essential for mucosal host defense against oral candidiasis. J Exp Med 2009; 206(2): 299-311.

96. Puel A, Cypowyj S, Marodi L, Abel L, Picard C, Casanova JL. Inborn errors of human IL-17 immunity underlie chronic mucocutaneous candidiasis. Curr Opin Allergy Clin Immunol 2012; 12(6): 616-622.

97. Ferreira MC, Whibley N, Mamo AJ, Siebenlist U, Chan YR, Gaffen SL. Interleukin-17-induced protein lipocalin 2 is dispensable for immunity to oral candidiasis. Infect Immun 2014; 82(3): 1030-1035.

98. Ho AW, Shen F, Conti HR, Patel N, Childs EE, Peterson AC et al. IL-17RC is required for immune signaling via an extended SEF/L-17R signaling domain in the cytoplasmic tail. $J$ Immunol 2010; 185(2): 1063-1070.

99. Kagami S, Rizzo HL, Kurtz SE, Miller LS, Blauvelt A. IL-23 and IL-17A, but not IL-12 and IL-22, are required for optimal skin host defense against Candida albicans. J Immunol 2010; 185(9): $5453-5462$.

100. Huang $\mathrm{W}, \mathrm{Na}$ L, Fidel PL, Schwarzenberger P. Requirement of interleukin-17A for systemic anti-Candida albicans host defense in mice. J Infect Dis 2004; 190(3): 624-631.

101. Saijo S, Ikeda S, Yamabe K, Kakuta S, Ishigame H, Akitsu A et al. Dectin-2 recognition of alpha-mannans and induction of Th17 cell differentiation is essential for host defense against Candida albicans. Immunity 2010; 32(5): 681-691. 
102. van de Veerdonk FL, Kullberg BJ, Verschueren IC, Hendriks T, van der Meer JW, Joosten LA et al. Differential effects of IL-17 pathway in disseminated candidiasis and zymosan-induced multiple organ failure. Shock 2010; 34(4): 407-411.

103. Whibley N, Gaffen SL. Brothers in arms: Th17 and Treg responses in Candida albicans immunity. PLoS Pathog 2014; 10(12): e1004456.

104. Hernandez-Santos N, Huppler AR, Peterson AC, Khader SA, McKenna KC, Gaffen SL. Th17 cells confer long-term adaptive immunity to oral mucosal Candida albicans infections. Mucosal Immunol 2013; 6(5): 900-910.

105. Symonds EL, Riedel CU, O'Mahony D, Lapthorne S, O'Mahony L, Shanahan F. Involvement of $\mathrm{T}$ helper type 17 and regulatory $\mathrm{T}$ cell activity in Citrobacter rodentium invasion and inflammatory damage. Clin Exp Immunol 2009; 157(1): 148-154.

106. Ishigame $\mathrm{H}$, Kakuta $\mathrm{S}$, Nagai $\mathrm{T}$, Kadoki M, Nambu A, Komiyama $\mathrm{Y}$ et al. Differential roles of interleukin-17A and -17F in host defense against mucoepithelial bacterial infection and allergic responses. Immunity 2009; 30(1): 108-119.

107. Cella M, Fuchs A, Vermi W, Facchetti F, Otero K, Lennerz JK et al. A human natural killer cell subset provides an innate source of IL-22 for mucosal immunity. Nature 2009; 457(7230): 722725.

108. Sanos SL, Bui VL, Mortha A, Oberle K, Heners C, Johner C et al. RORgammat and commensal microflora are required for the differentiation of mucosal interleukin 22-producing NKp46+ cells. Nat Immunol 2009; 10(1): 83-91.

109. Satoh-Takayama N, Vosshenrich CA, Lesjean-Pottier S, Sawa S, Lochner M, Rattis F et al. Microbial flora drives interleukin 22 production in intestinal NKp46+ cells that provide innate mucosal immune defense. Immunity 2008; 29(6): 958-970.

110. Sonnenberg GF, Monticelli LA, Elloso MM, Fouser LA, Artis D. CD4(+) lymphoid tissue-inducer cells promote innate immunity in the gut. Immunity 2011; 34(1): 122-134.

111. Zheng Y, Valdez PA, Danilenko DM, Hu Y, Sa SM, Gong Q et al. Interleukin-22 mediates early host defense against attaching and effacing bacterial pathogens. Nat Med 2008; 14(3): 282289.

112. Manta C, Heupel E, Radulovic K, Rossini V, Garbi N, Riedel CU et al. CX(3)CR1(+) macrophages support IL-22 production by innate lymphoid cells during infection with Citrobacter rodentium. Mucosal Immunol 2013; 6(1): 177-188.

113. Geddes K, Rubino SJ, Magalhaes JG, Streutker C, Le Bourhis L, Cho JH et al. Identification of an innate $T$ helper type 17 response to intestinal bacterial pathogens. Nat Med 2011; 17(7): 837-844.

114. Zelante T, De Luca A, Bonifazi P, Montagnoli C, Bozza S, Moretti S et al. IL-23 and the Th17 pathway promote inflammation and impair antifungal immune resistance. Eur J Immunol 2007; 37(10): 2695-2706.

115. Caruso R, Fina D, Paoluzi OA, Del Vecchio Blanco G, Stolfi C, Rizzo A et al. IL-23-mediated regulation of IL-17 production in Helicobacter pylori-infected gastric mucosa. Eur J Immunol 2008; 38(2): 470-478.

116. Luzza F, Parrello T, Monteleone G, Sebkova L, Romano M, Zarrilli R et al. Up-regulation of IL17 is associated with bioactive IL-8 expression in Helicobacter pylori-infected human gastric mucosa. J Immunol 2000; 165(9): 5332-5337.

117. Way EE, Chen K, Kolls JK. Dysregulation in lung immunity - the protective and pathologic Th17 response in infection. Eur J Immunol 2013; 43(12): 3116-3124. 
118. Wiehler S, Proud D. Interleukin-17A modulates human airway epithelial responses to human rhinovirus infection. Am J Physiol Lung Cell Mol Physiol 2007; 293(2): L505-515.

119. Singh RP, Hasan S, Sharma S, Nagra S, Yamaguchi DT, Wong DT et al. Th17 cells in inflammation and autoimmunity. Autoimmun Rev 2014; 13(12): 1174-1181.

120. Singh RP, Hasan S, Sharma S, Nagra S, Yamaguchi DT, Wong D et al. Th17 cells in inflammation and autoimmunity. Autoimmun Rev 2014.

121. Gaffen SL, Jain R, Garg AV, Cua DJ. The IL-23-IL-17 immune axis: from mechanisms to therapeutic testing. Nat Rev Immunol 2014; 14(9): 585-600.

122. Hueber W, Sands BE, Lewitzky S, Vandemeulebroecke M, Reinisch W, Higgins PD et al. Secukinumab, a human anti-IL-17A monoclonal antibody, for moderate to severe Crohn's disease: unexpected results of a randomised, double-blind placebo-controlled trial. Gut 2012; 61(12): 1693-1700.

123. Targan SR, Feagan BG, Vermeire S, Panaccione R, Melmed GY, Blosch C et al. A Randomized, Double-Blind, Placebo-Controlled Study to Evaluate the Safety, Tolerability, and Efficacy of AMG 827 in Subjects With Moderate to Severe Crohn's Disease. Gastroenterology 2012; 143(3): E26-E26.

124. Duerr RH, Taylor KD, Brant SR, Rioux JD, Silverberg MS, Daly MJ et al. A genome-wide association study identifies IL23R as an inflammatory bowel disease gene. Science 2006; 314(5804): 1461-1463.

125. O'Connor W, Jr., Kamanaka M, Booth CJ, Town T, Nakae S, Iwakura $Y$ et al. A protective function for interleukin 17A in T cell-mediated intestinal inflammation. Nat Immunol 2009; 10(6): 603-609.

126. Ogawa A, Andoh A, Araki Y, Bamba T, Fujiyama Y. Neutralization of interleukin-17 aggravates dextran sulfate sodium-induced colitis in mice. Clin Immunol 2004; 110(1): 55-62.

127. Yi T, Zhao D, Lin CL, Zhang C, Chen Y, Todorov I et al. Absence of donor Th17 leads to augmented Th1 differentiation and exacerbated acute graft-versus-host disease. Blood 2008; 112(5): 2101-2110.

128. Sakaguchi S, Sakaguchi N, Asano M, Itoh M, Toda M. Immunologic self-tolerance maintained by activated T cells expressing IL-2 receptor alpha-chains (CD25). Breakdown of a single mechanism of self-tolerance causes various autoimmune diseases. J Immunol 1995; 155(3): 1151-1164.

129. Clark LB, Appleby MW, Brunkow ME, Wilkinson JE, Ziegler SF, Ramsdell F. Cellular and molecular characterization of the scurfy mouse mutant. J Immunol 1999; 162(5): 2546-2554.

130. Lyon MF, Peters J, Glenister PH, Ball S, Wright E. The scurfy mouse mutant has previously unrecognized hematological abnormalities and resembles Wiskott-Aldrich syndrome. Proc Natl Acad Sci U S A 1990; 87(7): 2433-2437.

131. Wildin RS, Ramsdell F, Peake J, Faravelli F, Casanova JL, Buist $\mathrm{N}$ et al. X-linked neonatal diabetes mellitus, enteropathy and endocrinopathy syndrome is the human equivalent of mouse scurfy. Nat Genet 2001; 27(1): 18-20.

132. Bennett $\mathrm{CL}$, Christie J, Ramsdell F, Brunkow ME, Ferguson PJ, Whitesell $L$ et al. The immune dysregulation, polyendocrinopathy, enteropathy, X-linked syndrome (IPEX) is caused by mutations of FOXP3. Nat Genet 2001; 27(1): 20-21.

133. Brunkow ME, Jeffery EW, Hjerrild KA, Paeper B, Clark LB, Yasayko SA et al. Disruption of a new forkhead/winged-helix protein, scurfin, results in the fatal lymphoproliferative disorder of the scurfy mouse. Nat Genet 2001; 27(1): 68-73. 
134. Fontenot JD, Rasmussen JP, Williams LM, Dooley JL, Farr AG, Rudensky AY. Regulatory T cell lineage specification by the forkhead transcription factor foxp3. Immunity 2005; 22(3): 329-341.

135. Hori $\mathrm{S}$, Nomura $\mathrm{T}$, Sakaguchi $\mathrm{S}$. Control of regulatory $\mathrm{T}$ cell development by the transcription factor Foxp3. Science 2003; 299(5609): 1057-1061.

136. Kim JM, Rasmussen JP, Rudensky AY. Regulatory T cells prevent catastrophic autoimmunity throughout the lifespan of mice. Nat Immunol 2007; 8(2): 191-197.

137. Lahl K, Loddenkemper C, Drouin C, Freyer J, Arnason J, Eberl G et al. Selective depletion of Foxp3+ regulatory T cells induces a scurfy-like disease. J Exp Med 2007; 204(1): 57-63.

138. Suffner J, Hochweller K, Kuhnle MC, Li X, Kroczek RA, Garbi N et al. Dendritic cells support homeostatic expansion of Foxp3+ regulatory T cells in Foxp3.LuciDTR mice. J Immunol 2010; 184(4): 1810-1820.

139. Berod L, Puttur F, Huehn J, Sparwasser T. Tregs in infection and vaccinology: heroes or traitors? Microb Biotechnol 2012; 5(2): 260-269.

140. Kim J, Lahl K, Hori S, Loddenkemper C, Chaudhry A, deRoos P et al. Cutting edge: depletion of Foxp3+ cells leads to induction of autoimmunity by specific ablation of regulatory $T$ cells in genetically targeted mice. J Immunol 2009; 183(12): 7631-7634.

141. Klages K, Mayer CT, Lahl K, Loddenkemper C, Teng MW, Ngiow SF et al. Selective depletion of Foxp3+ regulatory $\mathrm{T}$ cells improves effective therapeutic vaccination against established melanoma. Cancer Res 2010; 70(20): 7788-7799.

142. Haribhai D, Lin W, Edwards B, Ziegelbauer J, Salzman NH, Carlson MR et al. A central role for induced regulatory $T$ cells in tolerance induction in experimental colitis. J Immunol 2009; 182(6): 3461-3468.

143. Josefowicz SZ, Niec RE, Kim HY, Treuting $P$, Chinen $T$, Zheng $Y$ et al. Extrathymically generated regulatory T cells control mucosal TH2 inflammation. Nature 2012; 482(7385): 395399.

144. Lathrop SK, Bloom SM, Rao SM, Nutsch K, Lio CW, Santacruz N et al. Peripheral education of the immune system by colonic commensal microbiota. Nature 2011; 478(7368): 250-254.

145. Samstein RM, Josefowicz SZ, Arvey A, Treuting PM, Rudensky AY. Extrathymic generation of regulatory $T$ cells in placental mammals mitigates maternal-fetal conflict. Cell 2012; 150(1): 2938.

146. Yang XO, Nurieva R, Martinez GJ, Kang HS, Chung Y, Pappu BP et al. Molecular antagonism and plasticity of regulatory and inflammatory T cell programs. Immunity 2008; 29(1): 44-56.

147. Zhou L, Lopes JE, Chong MM, Ivanov, II, Min R, Victora GD et al. TGF-beta-induced Foxp3 inhibits $\mathrm{T}(\mathrm{H}) 17$ cell differentiation by antagonizing RORgammat function. Nature 2008; 453(7192): 236-240.

148. Ichiyama K, Yoshida H, Wakabayashi $\mathrm{Y}$, Chinen T, Saeki K, Nakaya M et al. Foxp3 inhibits RORgammat-mediated IL-17A mRNA transcription through direct interaction with RORgammat. J Biol Chem 2008; 283(25): 17003-17008.

149. Chen Z, Barbi J, Bu S, Yang HY, Li Z, Gao Y et al. The ubiquitin ligase Stub1 negatively modulates regulatory $T$ cell suppressive activity by promoting degradation of the transcription factor Foxp3. Immunity 2013; 39(2): 272-285.

150. Noack M, Miossec $P$. Th17 and regulatory $T$ cell balance in autoimmune and inflammatory diseases. Autoimmun Rev 2014; 13(6): 668-677. 
151. Osorio F, LeibundGut-Landmann S, Lochner M, Lahl K, Sparwasser T, Eberl G et al. DC activated via dectin-1 convert Treg into IL-17 producers. Eur J Immunol 2008; 38(12): 32743281.

152. Li L, Kim J, Boussiotis VA. IL-1beta-mediated signals preferentially drive conversion of regulatory $\mathrm{T}$ cells but not conventional T cells into IL-17-producing cells. J Immunol 2010; 185(7): 4148-4153.

153. Li L, Patsoukis N, Petkova V, Boussiotis VA. Runx1 and Runx3 are involved in the generation and function of highly suppressive IL-17-producing T regulatory cells. PLoS One 2012; 7(9): e45115.

154. Esposito M, Ruffini F, Bergami A, Garzetti L, Borsellino G, Battistini L et al. IL-17- and IFNgamma-secreting Foxp3+ $\mathrm{T}$ cells infiltrate the target tissue in experimental autoimmunity. $\mathrm{J}$ Immunol 2010; 185(12): 7467-7473.

155. Tartar DM, VanMorlan AM, Wan X, Guloglu FB, Jain R, Haymaker CL et al. FoxP3+RORgammat+ $\mathrm{T}$ helper intermediates display suppressive function against autoimmune diabetes. J Immunol 2010; 184(7): 3377-3385.

156. Komatsu N, Okamoto K, Sawa S, Nakashima T, Oh-hora M, Kodama T et al. Pathogenic conversion of Foxp3+ T cells into TH17 cells in autoimmune arthritis. Nat Med 2014; 20(1): 6268.

157. Floess S, Freyer J, Siewert C, Baron U, Olek S, Polansky J et al. Epigenetic control of the foxp3 locus in regulatory T cells. PLoS Biol 2007; 5(2): e38.

158. Miyao T, Floess S, Setoguchi R, Luche H, Fehling HJ, Waldmann H et al. Plasticity of Foxp3(+) $T$ cells reflects promiscuous Foxp3 expression in conventional $T$ cells but not reprogramming of regulatory T cells. Immunity 2012; 36(2): 262-275.

159. Ohkura N, Hamaguchi M, Morikawa $H$, Sugimura $\mathrm{K}$, Tanaka $A$, Ito $\mathrm{Y}$ et al. $\mathrm{T}$ cell receptor stimulation-induced epigenetic changes and Foxp3 expression are independent and complementary events required for Treg cell development. Immunity 2012; 37(5): 785-799.

160. Polansky JK, Kretschmer K, Freyer J, Floess S, Garbe A, Baron U et al. DNA methylation controls Foxp3 gene expression. Eur J Immunol 2008; 38(6): 1654-1663.

161. Miyara M, Yoshioka Y, Kitoh A, Shima T, Wing K, Niwa A et al. Functional delineation and differentiation dynamics of human CD4+ T cells expressing the FoxP3 transcription factor. Immunity 2009; 30(6): 899-911.

162. Huehn J, Hamann A. Homing to suppress: address codes for Treg migration. Trends Immunol 2005; 26(12): 632-636.

163. Liston A, Gray DH. Homeostatic control of regulatory T cell diversity. Nat Rev Immunol 2014; 14(3): 154-165.

164. Feuerer M, Hill JA, Kretschmer K, von Boehmer H, Mathis D, Benoist C. Genomic definition of multiple ex vivo regulatory T cell subphenotypes. Proc Natl Acad Sci U S A 2010; 107(13): 5919-5924.

165. Delacher M, Schreiber L, Richards DM, Farah C, Feuerer M, Huehn J. Transcriptional Control of Regulatory T cells. Curr Top Microbiol Immunol 2014; 381: 83-124.

166. Koch MA, Tucker-Heard G, Perdue NR, Killebrew JR, Urdahl KB, Campbell DJ. The transcription factor $\mathrm{T}$-bet controls regulatory $\mathrm{T}$ cell homeostasis and function during type 1 inflammation. Nat Immunol 2009; 10(6): 595-602.

167. Wang $Y$, Su MA, Wan YY. An essential role of the transcription factor GATA-3 for the function of regulatory T cells. Immunity 2011; 35(3): 337-348. 
168. Wohlfert EA, Grainger JR, Bouladoux N, Konkel JE, Oldenhove G, Ribeiro $\mathrm{CH}$ et al. GATA3 controls Foxp3(+) regulatory T cell fate during inflammation in mice. J Clin Invest 2011; 121(11): 4503-4515.

169. Cretney E, Kallies A, Nutt SL. Differentiation and function of Foxp3(+) effector regulatory T cells. Trends Immunol 2013; 34(2): 74-80.

170. Cretney E, Xin A, Shi W, Minnich M, Masson F, Miasari M et al. The transcription factors Blimp1 and IRF4 jointly control the differentiation and function of effector regulatory $\mathrm{T}$ cells. Nat Immunol 2011; 12(4): 304-311.

171. Ayyoub M, Deknuydt F, Raimbaud I, Dousset C, Leveque L, Bioley G et al. Human memory FOXP3+ Tregs secrete IL-17 ex vivo and constitutively express the $T(H) 17$ lineage-specific transcription factor RORgamma t. Proc Natl Acad Sci U S A 2009; 106(21): 8635-8640.

172. Beriou G, Costantino CM, Ashley CW, Yang L, Kuchroo VK, Baecher-Allan C et al. IL-17producing human peripheral regulatory T cells retain suppressive function. Blood 2009; 113(18): 4240-4249.

173. Voo KS, Wang YH, Santori FR, Boggiano C, Wang YH, Arima $\mathrm{K}$ et al. Identification of IL-17producing FOXP3+ regulatory T cells in humans. Proc Natl Acad Sci U S A 2009; 106(12): 4793-4798.

174. Kryczek I, Wu K, Zhao E, Wei S, Vatan L, Szeliga W et al. IL-17+ regulatory T cells in the microenvironments of chronic inflammation and cancer. J Immunol 2011; 186(7): 4388-4395.

175. Nyirenda MH, Sanvito L, Darlington PJ, O'Brien K, Zhang GX, Constantinescu CS et al. TLR2 stimulation drives human naive and effector regulatory $T$ cells into a Th17-like phenotype with reduced suppressive function. $\mathrm{J}$ Immunol 2011; 187(5): 2278-2290.

176. Nyirenda MH, Morandi E, Vinkemeier U, Constantin-Teodosiu D, Drinkwater S, Mee M et al. TLR2 Stimulation Regulates the Balance between Regulatory T Cell and Th17 Function: A Novel Mechanism of Reduced Regulatory T Cell Function in Multiple Sclerosis. J Immunol 2015.

177. Koenen HJ, Smeets RL, Vink PM, van Rijssen E, Boots AM, Joosten I. Human CD25highFoxp3pos regulatory T cells differentiate into IL-17-producing cells. Blood 2008; 112(6): 2340-2352.

178. Valmori D, Raffin C, Raimbaud I, Ayyoub M. Human RORgammat+ TH17 cells preferentially differentiate from naive FOXP3+Treg in the presence of lineage-specific polarizing factors. Proc Natl Acad Sci U S A 2010; 107(45): 19402-19407.

179. Benson MJ, Pino-Lagos K, Rosemblatt M, Noelle RJ. All-trans retinoic acid mediates enhanced T reg cell growth, differentiation, and gut homing in the face of high levels of co-stimulation. $J$ Exp Med 2007; 204(8): 1765-1774.

180. Coombes JL, Siddiqui KR, Arancibia-Carcamo CV, Hall J, Sun CM, Belkaid $Y$ et al. A functionally specialized population of mucosal CD103+ DCs induces Foxp3+ regulatory T cells via a TGF-beta and retinoic acid-dependent mechanism. J Exp Med 2007; 204(8): 1757-1764.

181. Sun CM, Hall JA, Blank RB, Bouladoux N, Oukka M, Mora JR et al. Small intestine lamina propria dendritic cells promote de novo generation of Foxp3 $T$ reg cells via retinoic acid. $J$ Exp Med 2007; 204(8): 1775-1785.

182. Arpaia N, Campbell C, Fan X, Dikiy S, van der Veeken J, deRoos P et al. Metabolites produced by commensal bacteria promote peripheral regulatory T-cell generation. Nature 2013; 504(7480): 451-455.

183. Furusawa $Y$, Obata $Y$, Fukuda S, Endo TA, Nakato G, Takahashi D et al. Commensal microbederived butyrate induces the differentiation of colonic regulatory T cells. Nature 2013; 504(7480): 446-450. 
184. Smith PM, Howitt MR, Panikov N, Michaud M, Gallini CA, Bohlooly YM et al. The microbial metabolites, short-chain fatty acids, regulate colonic Treg cell homeostasis. Science 2013; 341(6145): 569-573.

185. Basu R, Whitley SK, Bhaumik S, Zindl CL, Schoeb TR, Benveniste EN et al. IL-1 signaling modulates activation of STAT transcription factors to antagonize retinoic acid signaling and control the TH17 cell-iTreg cell balance. Nat Immunol 2015; 16(3): 286-295.

186. Chaudhry A, Samstein RM, Treuting P, Liang Y, Pils MC, Heinrich JM et al. Interleukin-10 signaling in regulatory $\mathrm{T}$ cells is required for suppression of Th17 cell-mediated inflammation. Immunity 2011; 34(4): 566-578.

187. Huber S, Gagliani N, Esplugues E, O'Connor W, Jr., Huber FJ, Chaudhry A et al. Th17 cells express interleukin-10 receptor and are controlled by Foxp3(-) and Foxp3+ regulatory CD4+ T cells in an interleukin-10-dependent manner. Immunity 2011; 34(4): 554-565.

188. Joller N, Lozano E, Burkett PR, Patel B, Xiao S, Zhu C et al. Treg cells expressing the coinhibitory molecule TIGIT selectively inhibit proinflammatory Th1 and Th17 cell responses. Immunity 2014; 40(4): 569-581.

189. Yu X, Harden K, Gonzalez LC, Francesco M, Chiang E, Irving B et al. The surface protein TIGIT suppresses $T$ cell activation by promoting the generation of mature immunoregulatory dendritic cells. Nat Immunol 2009; 10(1): 48-57.

190. Chen Y, Haines CJ, Gutcher I, Hochweller K, Blumenschein WM, McClanahan T et al. Foxp3(+) regulatory $\mathrm{T}$ cells promote $\mathrm{T}$ helper 17 cell development in vivo through regulation of interleukin2. Immunity 2011; 34(3): 409-421.

191. Leon B, Bradley JE, Lund FE, Randall TD, Ballesteros-Tato A. FoxP3+ regulatory T cells promote influenza-specific Tfh responses by controlling IL-2 availability. Nat Commun 2014; 5: 3495.

192. Izcue A, Coombes JL, Powrie F. Regulatory lymphocytes and intestinal inflammation. Annu Rev Immunol 2009; 27: 313-338.

193. Sujino T, Kanai T, Ono $\mathrm{Y}$, Mikami $\mathrm{Y}$, Hayashi $\mathrm{A}$, Doi $\mathrm{T}$ et al. Regulatory $\mathrm{T}$ cells suppress development of colitis, blocking differentiation of T-helper 17 into alternative T-helper 1 cells. Gastroenterology 2011; 141(3): 1014-1023.

194. Davidson TS, DiPaolo RJ, Andersson J, Shevach EM. Cutting Edge: IL-2 is essential for TGFbeta-mediated induction of Foxp3+ T regulatory cells. J Immunol 2007; 178(7): 4022-4026.

195. Sakaguchi S, Yamaguchi T, Nomura T, Ono M. Regulatory T cells and immune tolerance. Cell 2008; 133(5): 775-787.

196. Shevach EM. Application of IL-2 therapy to target T regulatory cell function. Trends Immunol 2012; 33(12): 626-632.

197. Laurence A, Tato CM, Davidson TS, Kanno Y, Chen Z, Yao Z et al. Interleukin-2 signaling via STAT5 constrains T helper 17 cell generation. Immunity 2007; 26(3): 371-381.

198. Moore-Connors JM, Fraser R, Halperin SA, Wang J. CD4(+)CD25(+)Foxp3(+) regulatory T cells promote Th17 responses and genital tract inflammation upon intracellular Chlamydia muridarum infection. J Immunol 2013; 191(6): 3430-3439.

199. Pandiyan P, Conti HR, Zheng L, Peterson AC, Mathern DR, Hernandez-Santos $\mathrm{N}$ et al. CD4(+)CD25(+)Foxp3(+) regulatory $\mathrm{T}$ cells promote Th17 cells in vitro and enhance host resistance in mouse Candida albicans Th17 cell infection model. Immunity 2011; 34(3): 422434. 
200. Wang Z, Friedrich C, Hagemann SC, Korte WH, Goharani N, Cording S et al. Regulatory T cells promote a protective Th17-associated immune response to intestinal bacterial infection with $\mathrm{C}$. rodentium. Mucosal Immunol 2014; 7(6): 1290-1301.

201. Amadi-Obi A, Yu CR, Liu X, Mahdi RM, Clarke GL, Nussenblatt RB et al. TH17 cells contribute to uveitis and scleritis and are expanded by IL-2 and inhibited by IL-27/STAT1. Nat Med 2007; 13(6): 711-718.

202. Gasteiger G, Hemmers S, Bos PD, Sun JC, Rudensky AY. IL-2-dependent adaptive control of NK cell homeostasis. J Exp Med 2013; 210(6): 1179-1187.

203. Gasteiger G, Hemmers S, Firth MA, Le Floc'h A, Huse M, Sun JC et al. IL-2-dependent tuning of NK cell sensitivity for target cells is controlled by regulatory T cells. J Exp Med 2013; 210(6): 1167-1178.

204. Barbi J, Pardoll D, Pan F. Metabolic control of the Treg/Th17 axis. Immunol Rev 2013; 252(1): 52-77. 
a Treg inhibit Th17 cell response

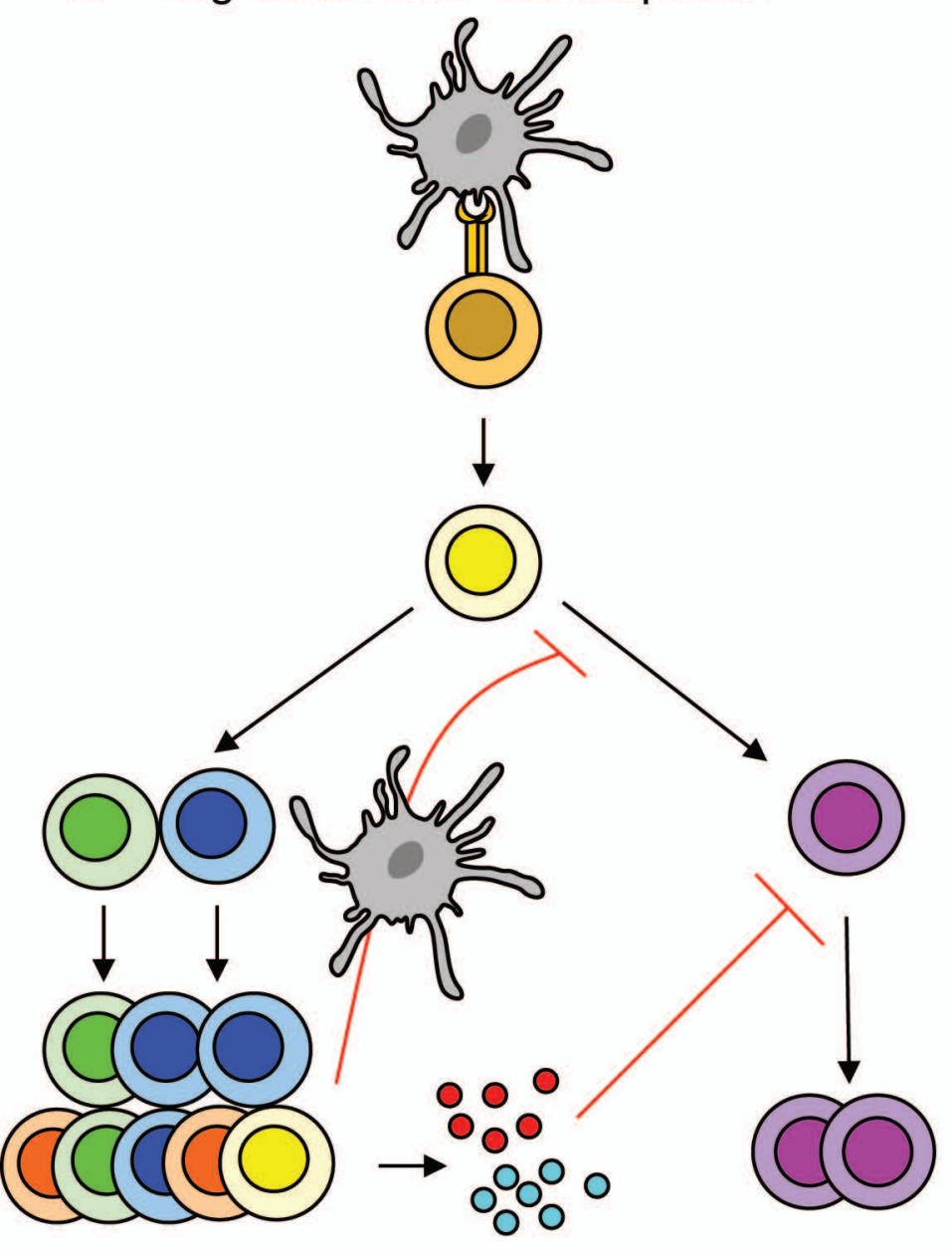

b Treg contribute to Th17 cell response

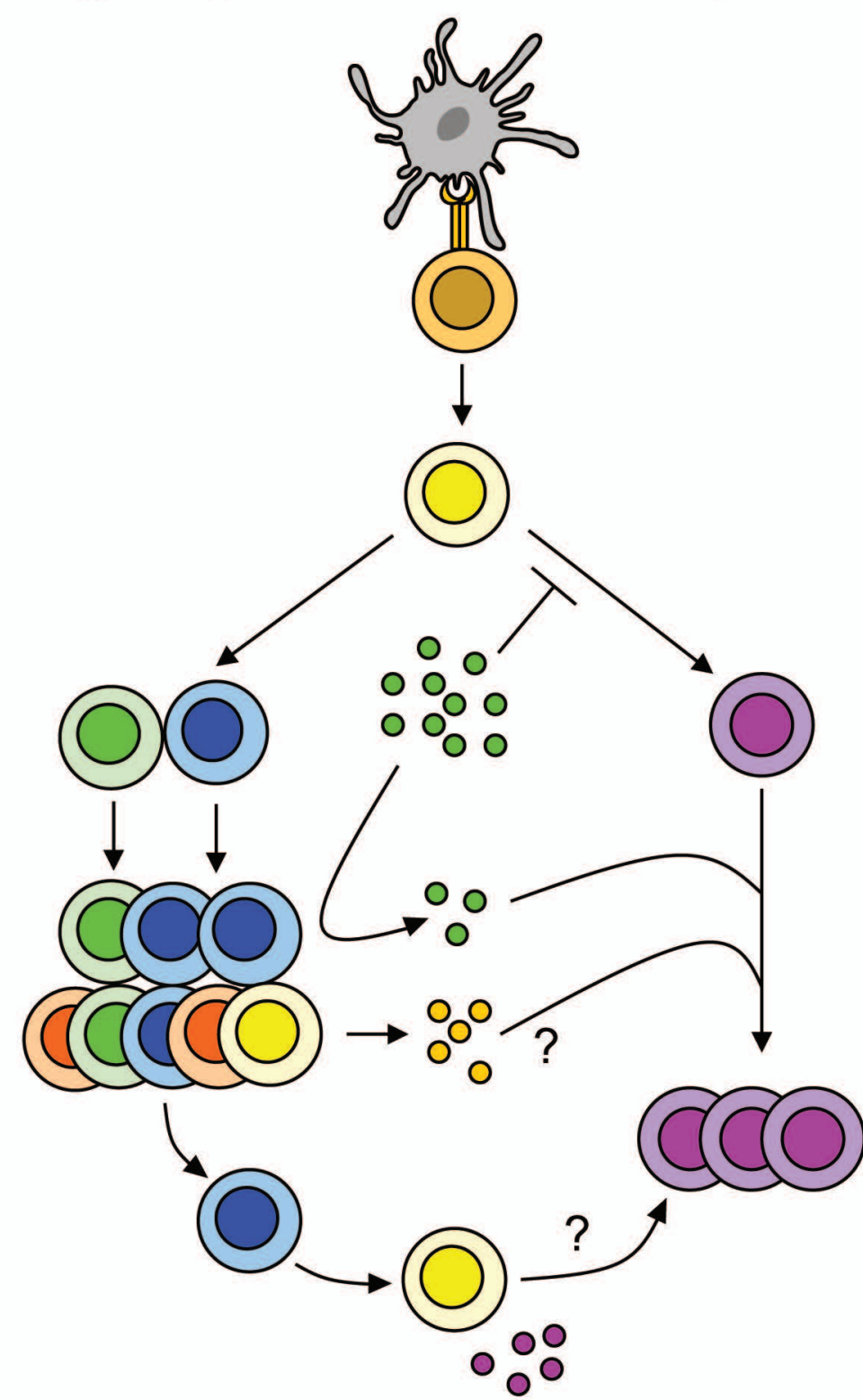

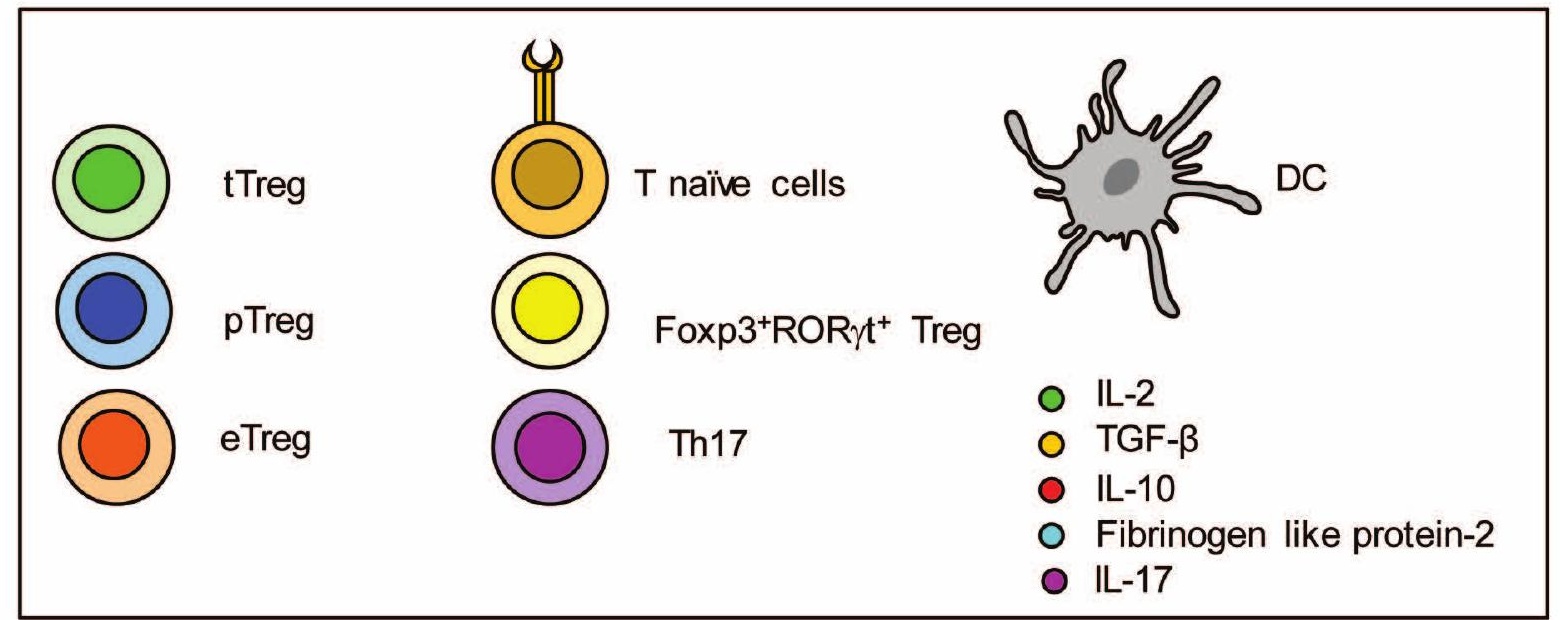

